\title{
New data on mineralogy of the Vysoký Kámen deposits near Krásno, Slavkovský les area, Czech Republic
}

\author{
Nové poznatky o mineralogii ložisek Vysoký Kámen u Krásna \\ (Slavkovský les, Česká republika)
}

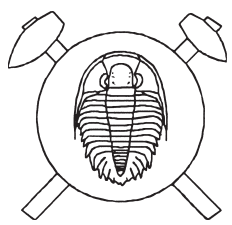

(32 figs, 11 tabs)

\author{
JIŘÍ SEJKORA ${ }^{1}$ - PETR ONDRUŠ ${ }^{2}$-MIROSLAV FIKAR ${ }^{3}$ - FRANTIŠEK VESELOVSKÝ² - ZDENĚK MACH ${ }^{4}-$ ANANDA GABAŠOVÁ $^{5}$ \\ ${ }^{1}$ Department of Mineralogy and Petrology, National Museum, Václavské nám. 68, CZ-115 79 Praha 1, Czech Republic \\ ${ }^{2}$ Biskupský dvưr 2, CZ-110 00 Praha 1, Czech Republic \\ ${ }^{3}$ Plaská 55, CZ-323 00 Plzeň, Czech Republic \\ ${ }^{4}$ Kolová 116, CZ-360 10 Karlovy Vary, Czech Republic \\ ${ }^{5}$ Czech Geological Survey, Klárov 3, CZ-118 21 Praha 1, Czech Republic
}

\begin{abstract}
Detailed mineralogical study focused on two deposits located on slopes of the Vysoký Kámen hill near Krásno in the proximity of the town of Horní Slavkov in Czech Republic. The open pit exploiting industrial feldspar material (mainly feldspathites and aplitic granites) offerred new finds of minerals in the Slavkovský les. The following minerals were identified: autunite, bertrandite, beryl, goethite, hematite, koechlinite, kolbeckite, meta-autunite, powellite and scheelite. In the nearby abandoned greisen deposit a phosphate mineral association was observed consisting of cacoxenite, leucophosphite, vivianite, wavellite and minerals of the chalcosiderite-turquoise and strengite-variscite series. In
\end{abstract} addition to them dickite and goethite were identified. The genesis of these mineral associations is discussed.

Key words: greisen; supergene minerals; phosphates; molybdates; wolframates; Vysoký Kámen near Krásno; Horní Slavkov; western Bohemia; Czech Republic

\section{Introduction}

The two studied deposits are both localized on the slopes of the elevation 819.4 m, west and northwest of Krásno, about $7 \mathrm{~km}$ south-southwest of Horní Slavkov in western Czech Republic. The first one is an abandoned Sn-W greisen deposit and the second one is feldspathite (feldspathite = leucocratic alkali feldspar syenite) body exploited presently as ceramic feldspar deposit. The greisen deposit was uncovered by an open pit (Fig. 1), directly at the NW edge of the Krásno village. During a recultivation the quarry was filled with various rock material. Thus the supergene* mineralization can be now observed only on a limited scale at the outcrop of a silicified fault zone exposed above the former quarry (Fig. 2). The feldspar deposit (called as Vysoký Kámen - feldspar, in the following text) is exploited by a quarry (Fig. 3) with several levels (Fig. 4), located on the northern slope of the elevation $819.4 \mathrm{~m}$, about $0.5 \mathrm{~km}$ west to northwest of the Krásno village.

\section{Geological situation of the Vysoký Kámen deposits}

The greisen stock at Vysoký Kámen is positioned southwest of the Schnöd stock, in extension of a line connecting the Schnöd and Huber granite stocks. It is located in an intrusion of a younger suite granite, i.e., classified with the Younger Intrusive Complex granite (YIC granite). The envelope to this granite body consists of migmatized biotite paragneiss, grading to medium-grained, advanced migmatites. A marginal pegmatite (stockscheider) is often present at the granite contact. The stock has an oval shape in plan, but the southwestern flank is cut off by a fault zone, uplifted and strongly eroded (Fig. 5). A breccia-textured quartz gangue, stained by iron oxides, fills the fault zone (Fig. 6). Thus, only a low core part of the stock, composed of aplitic granite with greisen relics, is preserved (Beran 1999).

Coarse-grained topaz-mica greisen builds the remaining part of the stock and downwards it passes to greisenized granite. The greisen body is composed of several mineral zones with a total thickness of 40 to $60 \mathrm{~m}$. In the central part, the greisen reaches upwards up to the

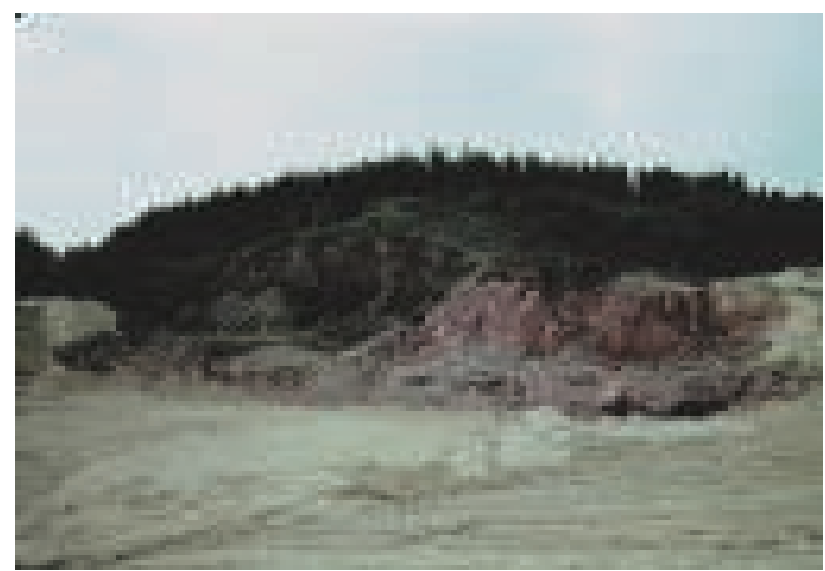

Fig. 1 Open pit at greisen deposit Vysoký Kámen near Krásno (photo P. Beran 1986)

\footnotetext{
* note by referee: the term supergene is used in a relatively loose sense, in agreement with common practice in mineralogical literature. Some publications on ore deposits use the term specifically for a certain part of the oxide zone (zone of supergene enrichment).
} 


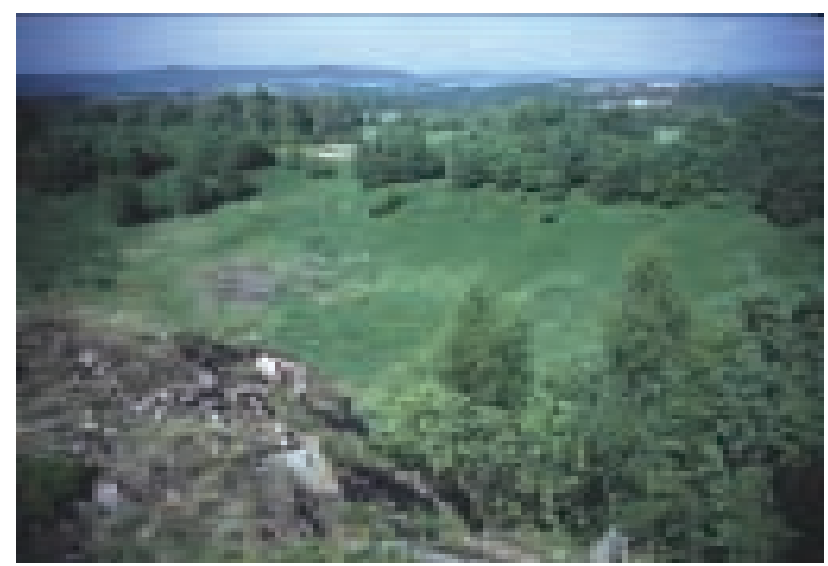

Fig. 2 Relics of open pit at greisen deposit Vysoký Kámen near Krásno after recultivation (photo J. Sejkora 2002) granite-gneiss contact. The outcrop of the stock at the present surface has approximately 200 by $300 \mathrm{~m}$ size, disregarding the uplifted southwestern part. At the margins the greisen body is split to several smaller parts which gradually wedge-out and pass to greisenized granite. The greisenized granite directly below greisen is strongly hydrothermally altered, mainly by kaolinization. Toward the deeper levels, the alteration dies out and the rock passes into a fresh Li-mica-topaz granite. Still to deeper levels, about $150 \mathrm{~m}$ below surface, the stock is composed of a leucocratic topaz granite, which gradually evolved from ordinary granite via the disappearance of Li-mica. The Sn-W mineralization at Vysoký Kámen is formed by cassiterite and subordinate wolframite impregnation in greisen and greisenized granite. Miner-

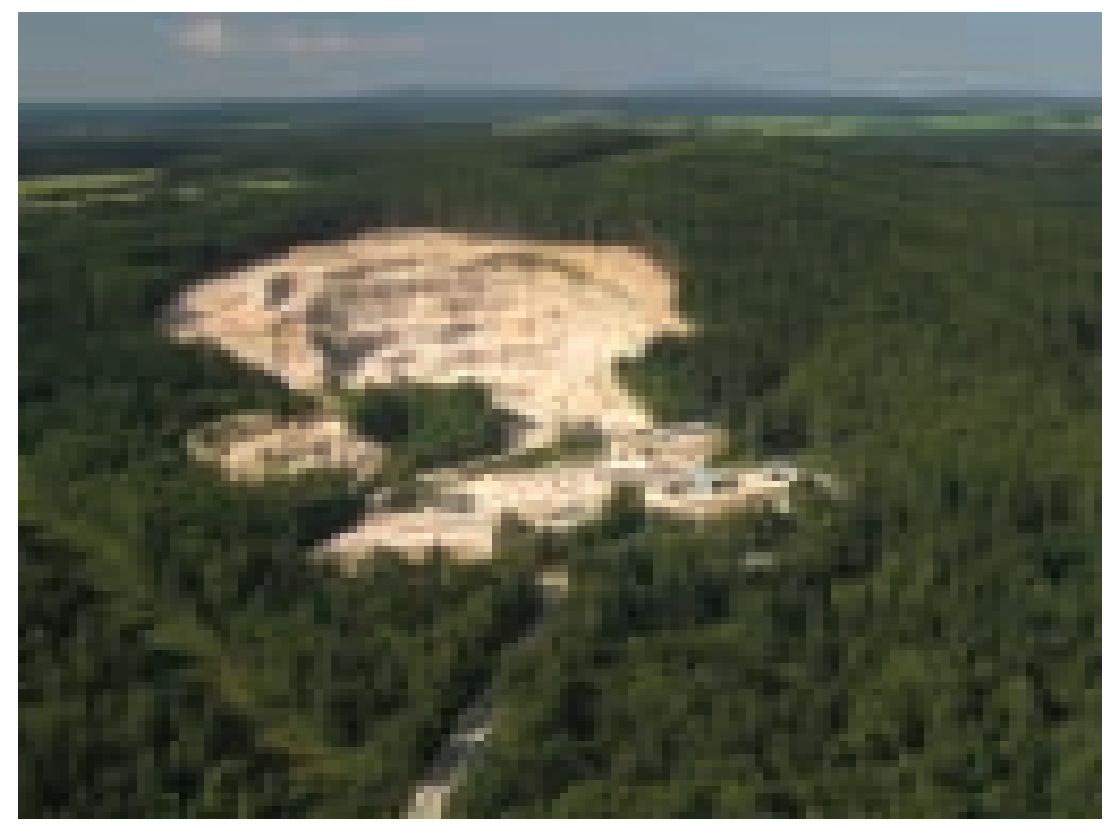

Fig. 3 Quarry at the Vysoký Kámen deposit near Krásno (feldspar) (photo J. Berger 2001)

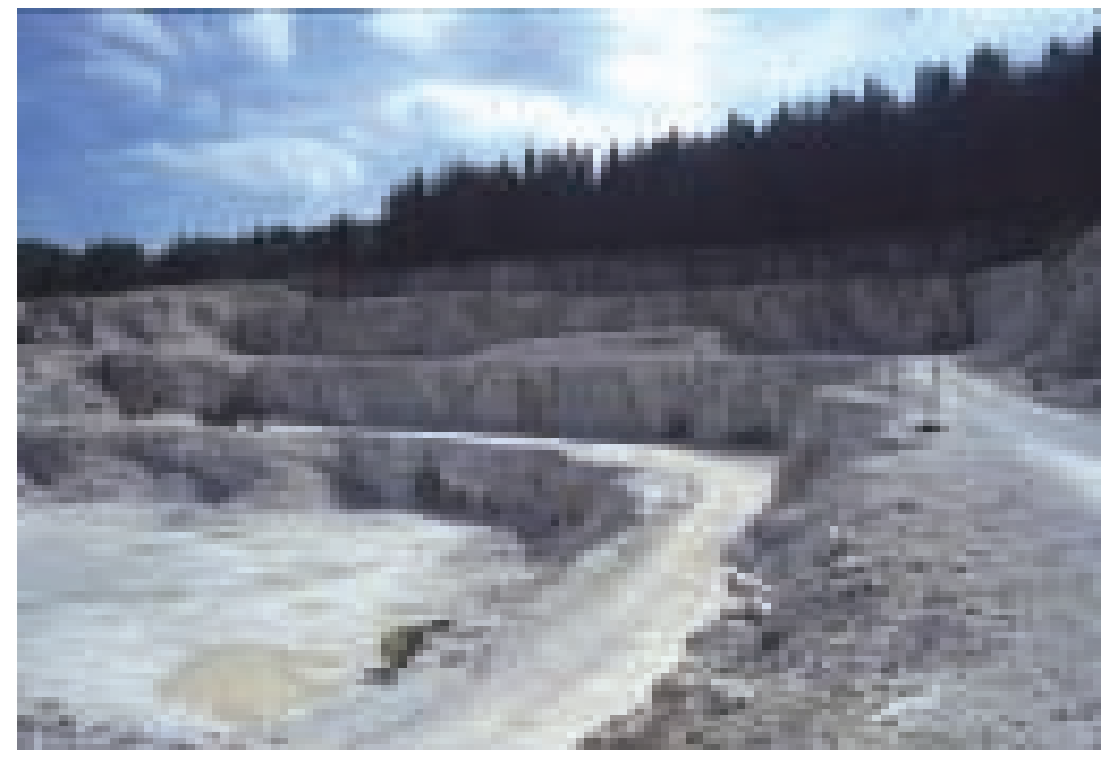

Fig. 4 Quarry at the Vysoký Kámen deposit near Krásno (feldspar) (photo J. Sejkora 2002) 


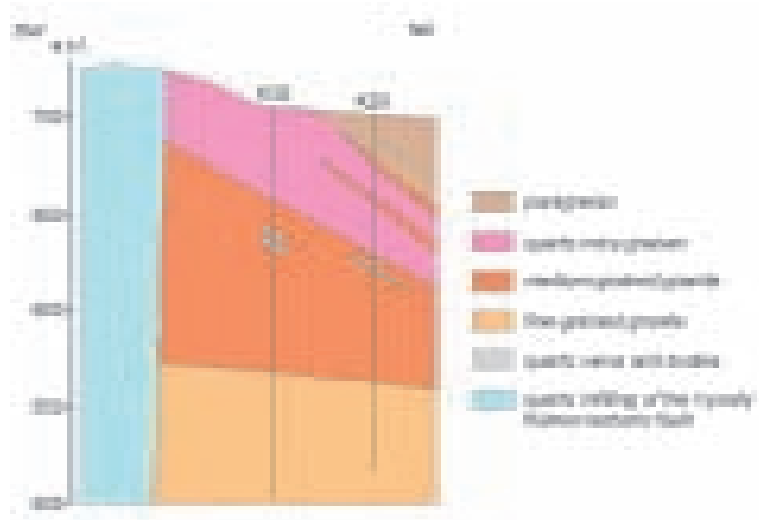

Fig. 5 Geological section of Vysoký Kámen (greisen) deposit, according to Janečka in Beran (1999).

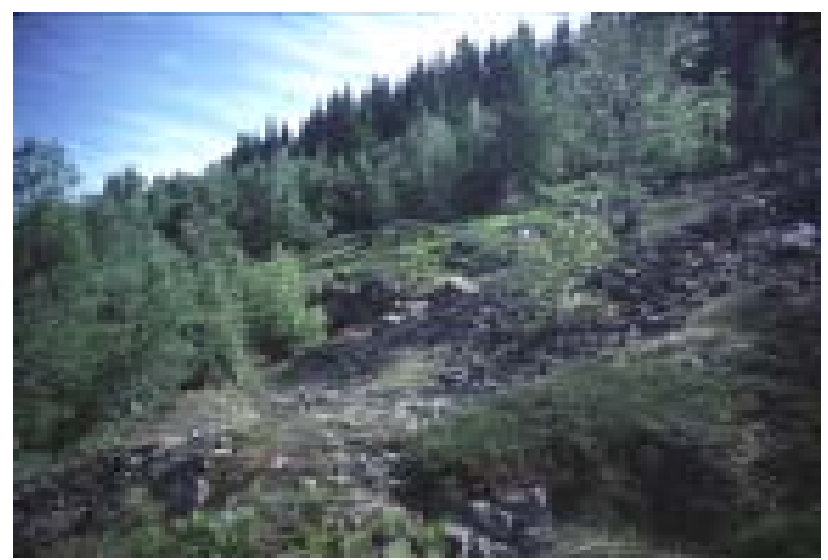

Fig. 6 Outcrops of quartz filling of the Vysoký Kámen tectonic fault (photo J. Sejkora 2002).

alized ore shoots are much smaller than the greisen bodies and they are always confined to the greisen interior. The shape of the ore shoots, as well as of greisen, is very irregular. The main ore body has a more simple shape and it is located in a distance of 3 to $8 \mathrm{~m}$ from the granite contact.

The feldspathite deposit (Vysoký Kámen - feldspar) represents a part of the granite stock which is greisenized at its contacts. At the east the stock is bound against the metamorphic rocks of the Slavkov gneiss roof pendant by a fault trending NW-SE (Vysoký Kámen fault). At the north Li-mica-topaz granite occurs, at the west the Šibeník type of muscovite granite, and at the east and southeast the stock contacts greisens. Feldspathites show gradual transitions to the enclosing granite, at some places they form layers, nests and tube-like bodies, at others they are accompanied by a pegmatite (Beran 1999). The outcrop of the deposit is 250 by $250 \mathrm{~m}$ in size. Reserves of feldspathites were measured also at the subsurface levels and extend downwards from the outcrop. Feldspathite layers, with the best raw-material quality, occur at a depth of $70 \mathrm{~m}$ from the surface (about $700 \mathrm{~m}$ a.s.1.). Altogether, feldspathite, aplitic granite, aplitic granite with a low mica content and rare pegmatites are exploited as a feldspar raw-material with a low content of iron oxides.

The majority of studied samples was collected at the lower level of the Vysoký Kámen feldspar quarry, near a branch of the fault zone filled in by jasper, quartz and clay minerals. A lenticular body of "vein-type greisen", up to $3 \mathrm{~m}$ wide, trending NE-SW and dipping 75 to $80^{\circ}$ SE was also observed there. This body has a core of recrystallized quartz with wolframite, molybdenite, bismuth etc., and an outer zone of muscovite, quartz, apatite, beryl and clay minerals formed by greisenization of coarsegrained feldspar. The body has an outer kaolinized rim. It is probable that the rock is rather a greisenized pegmatite than a vein-type greisen.

\section{Methods of mineral identification}

Surface morphology of the samples was studied using optical microscope Nikon SMZ 1500 in combination with digital camera Nikon DXM1200F for microphotography in incandescent light. Details of surface morphology were studied in secondary electron images with the electron scanning microscopes JEOL JSM T-20 (Z. Mach; Research Institute of Ceramics, Karlovy Vary - Březová) and Tesla BS 340 (A. Gabašová and J. Sejkora, Czech Geological Survey, Prague).

The X-ray powder diffraction analysis was used for identification of minerals. To minimize complicated shape of background due to classic glass sample holder, the samples studied were placed on the surface of flat silicon wafer from alcoholic suspension. Step-scanned powder diffraction data were collected using Philips X'Pert MPD diffractometer with a metallo-ceramic copper tube which was operated at high-voltage of $40 \mathrm{kV}$ and tube current of $40 \mathrm{~mA}$. A graphite secondary monochromator has been used to produce $\mathrm{CuK \alpha} \alpha_{1}$, radiation. In special cases a film methods - Gandolfi camera $114.6 \mathrm{~mm}(\mathrm{CoK} \alpha$ radiation) were used. The results were processed by using X-ray analysis software ZDS for DOS (Ondruš 1993), Bede ZDS Search/Match ver. 4.5 (Ondruš - Skála 1997); unit-cell parameters were refined by program FullProf (Rodríguez - Carvajal 2005).

We used energy dispersion analyser Tracor-Northern for qualitative chemical analysis (R. Rybka, Czech Geological Survey, Prague). Additional quantitative chemical analyses were made with the electron microprobe Cameca SX 100 (J. Sejkora and R. Škoda, Laboratory of electron microscopy and microanalysis of Masaryk University and Czech Geological Survey, Brno). Studied samples were mounted in epoxide resin discs and polished. The polished surfaces were coated with carbon layer $250 \AA$ thick. Wavelength dispersion mode and operating voltage $15 \mathrm{kV}$ were used in all analyses. Used beam current and diameter reflect stability of analyzed phases under electron beam. Stable phases were analyzed under $20 \mathrm{nA}$ current and $2 \mu \mathrm{m}$ beam size. Less stable and highly hydrated minerals were analyzed at conditions of $10-$ $4 \mathrm{nA}$ and 10-30 $\mu \mathrm{m}$ beam diameter. For smaller aggre- 
gates $(<10 \mu \mathrm{m})$ of unstable minerals the beam diameter was as large as possible and applied beam current was only 1-2 nA. The sequence of elements determination during analyzing was operatively changed according to chemical composition. Volatile and major elements were analyzed prior to stable, minor, and trace elements. Higher analytical totals of minerals containing higher amount of hydroxyl or crystalline water were generally caused by escape of water under high vacuum, well documented by a collapse of crystals or by electron beam heating during analysis, causing escape of water, documented as intensively bright spots after analysis. Lower analytical totals of some samples were primarily caused by the porous nature or by poorly polished surface of soft or cryptocrystalline minerals.

To minimize peaks overlapping, the following analytical lines and crystals were selected: K $\alpha$ lines: Al (TAP, sanidine), As (TAP, InAs), Cu (TAP, dioptas), P (PET, fluorapatite), $\mathrm{Ca}$ (PET, andradite), S (PET, barite), Fe (LIF, andradite), Zn (LIF, ZnO); Lß line: $\mathrm{Sr}$ (PET, SrSO $)$; Lß line: $\mathrm{Ba}$ (PET, benitoite); $\mathrm{M} \beta$ line: $\mathrm{Bi}$ (PET, metallic Bi). Peak counting times (CT) were 10 to $20 \mathrm{~s}$ for main elements and 30 to $60 \mathrm{~s}$ for minor and trace elements. CT for each background was $1 / 2$ of peak time. When only one background and appropriate slope had to be used, the background CT corresponded to peak CT. Applicable minor to trace elements were preferentially analyzed using high sensitivity large LPET and LLIF crystals. Raw intensities were converted to the concentrations using automatic PAP (Pouchou - Pichoir 1985) matrix correction software package.

Infrared spectra were recorded with PYE-UNICAMPHILIPS SP3-300 and Perkin Elmer 521. Spectra were measured from KBr tablets in the range of 4000-200 $\mathrm{cm}^{-1}$, time 7 minutes (O. Žilková, ÚVZÚ, Plzeň).

\section{Minerals identified at the Vysoký Kámen (feldspar) deposit}

\section{Autunite $\mathrm{Ca}\left(\mathrm{UO}_{2}\right)_{2}\left(\mathrm{PO}_{4}\right)_{2}$. 10-12 $\mathrm{H}_{2} \mathrm{O}$ and meta- autunite $\mathrm{Ca}\left(\mathrm{UO}_{2}\right)_{2}\left(\mathrm{PO}_{4}\right)_{2} .6 \mathrm{H}_{2} \mathrm{O}$}

Pauliš (1990) reported autunite as light yellow powdery aggregates passing to tetragonal crystals with pearly lustre, up to $3 \mathrm{~cm}$ in size. Autunite was observed in a steeply dipping fracture within the greisen, locally healed by finely crystalline quartz associated with goethite.

Meta-autunite occurs through the whole profile and at all levels of the quarry. The most common form is that of fine and inconspicuous impregnations in fractures of leucocratic granite and of greisen. Yellowish mixture with clay minerals in cracks and fissures represents another frequent form of meta-autunite occurrence. Imperfect tetragonal tabular crystals or crystalline crusts of light yellow or yellow colours are relatively rare. In a short-wave and long-wave UV light it shows very strong yellow green fluorescence. The unit-cell parameters (Table 1) correspond to the published data.
Table 1 Unit cell parameters of meta-autunite (tetragonal $\mathrm{P} 4 / \mathrm{nmm}$ )

\begin{tabular}{|c|cc|}
\hline & this paper & Makarov - Ivanov (1960) \\
\hline $\mathrm{a}[\AA]$ & $6.974(1)$ & $6.96(1)$ \\
$\mathrm{c}[\AA]$ & $8.451(2)$ & $8.40(2)$ \\
$\mathrm{V}\left[\AA^{3}\right]$ & 411.0 & 406.9 \\
\hline
\end{tabular}

\section{Bertrandite $\mathrm{Be}_{4} \mathrm{Si}_{2} \mathrm{O}_{7}(\mathrm{OH})_{2}$}

Bertrandite forms inconspicuous, thick tabular crystals up to $3 \mathrm{~mm}$ in size. They occur in greisen cavities on the crystals of quartz, rarely in the cavities after leached beryl in association with clay minerals, apatite and exceptionally with wolframite. Although the amount of leached beryl is notable at this locality, bertrandite is a rare mineral. It was also observed as aggregates of transparent acicular crystals up to $2 \mathrm{~mm}$ in size deposited on imperfect crystals of pink-beige apatite. Bertrandite has been observed close to corroded beryl only rarely, possibly due to relatively high mobility of Be ions. The unit-cell parameters (Table 2) correspond to published data.

Table 2 Unit cell parameters of bertrandite (orthorhombic $\mathrm{Cmc2}$ )

\begin{tabular}{|c|cc|}
\hline & this paper & Giuseppetti et al. $(1992)$ \\
\hline $\mathrm{a}[\AA]$ & $8.720(1)$ & $8.716(3)$ \\
$\mathrm{b}[\AA]$ & $15.2785(9)$ & $15.255(3)$ \\
$\mathrm{c}[\AA]$ & $4.5706(1)$ & $4.564(1)$ \\
$\mathrm{V}\left[\AA^{3}\right]$ & 608.93 & 607.0 \\
\hline
\end{tabular}

\section{Beryl $\mathrm{Be}_{3} \mathrm{Al}_{2} \mathrm{Si}_{6} \mathrm{O}_{18}$}

Beryl is a fairly common mineral in the greisen, as granular aggregates or perfectly formed crystals in vugs of greisen and quartz. The crystals are grey-brown, greyblue, light blue, white, or rare colourless translucent up to $12 \mathrm{~cm}$ long and $2.5 \mathrm{~cm}$ wide. Some aggregates form layers up to several dm long, with the grains which were hydrothermally strongly corroded (Beran 1999). Granular beryl aggregates of yellowish or greenish colour are also very frequent enclosing in places imperfect bluish and grey green prismatic crystals or radiating crystal groups up to $15 \mathrm{~cm}$ long. The occurrences of beryl were confirmed by X-ray powder diffraction data.

\section{Goethite $\mathrm{FeO}(\mathrm{OH})$}

It occurs as spheroidal radiating aggregates and small redbrown crystals in association with koechlinite-russellite, autunite, meta-autunite and powellite in the cavities of the quartz gangue. It is the youngest mineral in the mineral associations described. Goethite was identified by $\mathrm{X}$-ray powder diffraction data.

\section{Hematite $\mathrm{Fe}_{2} \mathrm{O}_{3}$}

Hematite occurs in radiating spheroidal aggregates composed of microscopic red brown acicular crystals. The 
aggregates are on average $5 \mathrm{~mm}$ in diameter and very similar to goethite aggregates. This type of hematite was deposited in some cavities in quartz and in fractures in the greisenized granite. Hematite along with goethite belong genetically to the youngest minerals at the deposit. Hematite was identified X-ray powder diffraction data.

\section{Koechlinite $(\mathrm{BiO})_{2} \mathrm{MoO}_{4}$}

Koechlinite is a common mineral in the "greisen" body forming usually powdery coatings and infilling of cavities after leached molybdenite. Imperfectly foliated, ductile crystals up to $0.1 \mathrm{~mm}$ are rare. The locality provided relatively rich samples with yellow koechlinite coatings several $\mathrm{cm}^{2}$ in size. Koechlinite was formed by decomposition of powellite and Bi was provided by native bismuth, observed as relics near some koechlinite occurrences.

Unit-cell parameters of koechlinite (Table 3) are in a good agreement with published data. Quantitative chemical analyses of koechlinite (Table 4) show, in addition to minor As and $\mathrm{P}$ contents, also minor $\mathrm{W}$. This indicates that the mineral has the composition close to the endmember of the isomorphous series koechlinite (Mo) - russellite $(\mathrm{W})$. Its chemical composition corresponds to the

Table 3 Unit cell parameters of koechlinite (orthorhombic Pca2 ${ }_{1}$ )

\begin{tabular}{|c|cc|}
\hline & this paper & Teller et al. $(1984)$ \\
\hline $\mathrm{a}[\AA]$ & $5.488(3)$ & $5.4822(3)$ \\
$\mathrm{b}[\AA]$ & $16.24(1)$ & $16.1986(8)$ \\
$\mathrm{c}[\AA]$ & $5.510(5)$ & $5.5091(3)$ \\
$\mathrm{V}\left[\AA^{3}\right]$ & 491.1 & 489.23 \\
\hline
\end{tabular}

Table 4 Chemical composition of koechlinite from Vysoký Kámen (feldspar) (in wt. \%)

\begin{tabular}{|l|rc|}
\hline & Vysoký Kámen & theoretical composition \\
\hline $\mathrm{Bi}_{2} \mathrm{O}_{3}$ & 75.85 & 76.40 \\
$\mathrm{As}_{2} \mathrm{O}_{5}$ & 0.22 & \\
$\mathrm{P}_{2} \mathrm{O}_{5}$ & 0.40 & \\
$\mathrm{MoO}_{3}$ & 20.98 & 23.60 \\
$\mathrm{WO}_{3}$ & 2.14 & \\
total & 99.56 & 100.00 \\
\hline
\end{tabular}

Table 5 Infrared spectrum of koechlinite from Vysoký Kámen

\begin{tabular}{|cccc|}
\hline$\left[\mathrm{cm}^{-1}\right]$ & $*$ & {$\left[\mathrm{~cm}^{-1}\right]$} & $*$ \\
\hline 320 & w & 1115 & $\mathrm{~m}, \mathrm{sh}$ \\
440 & w & 1275 & $\mathrm{~m}$ \\
570 & $\mathrm{w}$ & 1375 & $\mathrm{vw}$ \\
725 & $\mathrm{vs}$ & 1440 & $\mathrm{vw}$ \\
795 & $\mathrm{~s}, \mathrm{sh}$ & 1635 & $\mathrm{~m}$ \\
835 & $\mathrm{~s}$ & 1705 & $\mathrm{w}$ \\
1000 & $\mathrm{~m}, \mathrm{sh}$ & 2920 & $\mathrm{w}$ \\
1070 & $\mathrm{~m}$ & 3420 & $\mathrm{vw}, \mathrm{b}$ \\
\hline
\end{tabular}

* Character of absorption maxima:

sh - shoulder; b - broad. Intensity scale:

vs - very strong; s - strong; $\mathrm{m}$ - medium;

mw - medium weak; w - weak; vw - very weak.

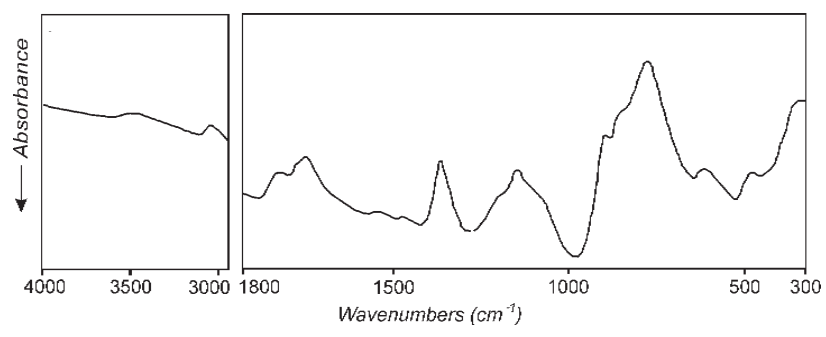

Fig. 7 The infrared spectra of koechlinite from Vysoký Kámen - feldspar, Krásno near Horní Slavkov.

following empirical formula, based on six oxygen atoms: $(\mathrm{BiO})_{2.00}\left(\mathrm{Mo}_{0.90} \mathrm{~W}_{0.06} \mathrm{P}_{0.02} \mathrm{As}_{0.01} \mathrm{O}_{4}\right)$. Beran (1999) reported an occurrence of intermediate members of the russellitekoechlinite series from the same greisen body. However, no analytical data support this information. The infrared spectrum of koechlinite from Vysoký Kámen is given in Table 5 and in Fig. 7. Bands at 320 and $720 \mathrm{~cm}^{-1}$ correspond to deformation vibration of the $\mathrm{BiO}^{+}$ion. Bands at $320,440,795,835,1000$ and $1070 \mathrm{~cm}^{-1}$ correspond to vibration of the $\left(\mathrm{MoO}_{4}\right)^{2-}$ anion.

\section{Kolbeckite $\mathrm{ScPO}_{4} \cdot 2 \mathrm{H}_{2} \mathrm{O}$}

Kolbeckite was found in several samples only as blue or grey blue crystals (Fig. 8) rarely up to $2 \mathrm{~mm}$ long, of

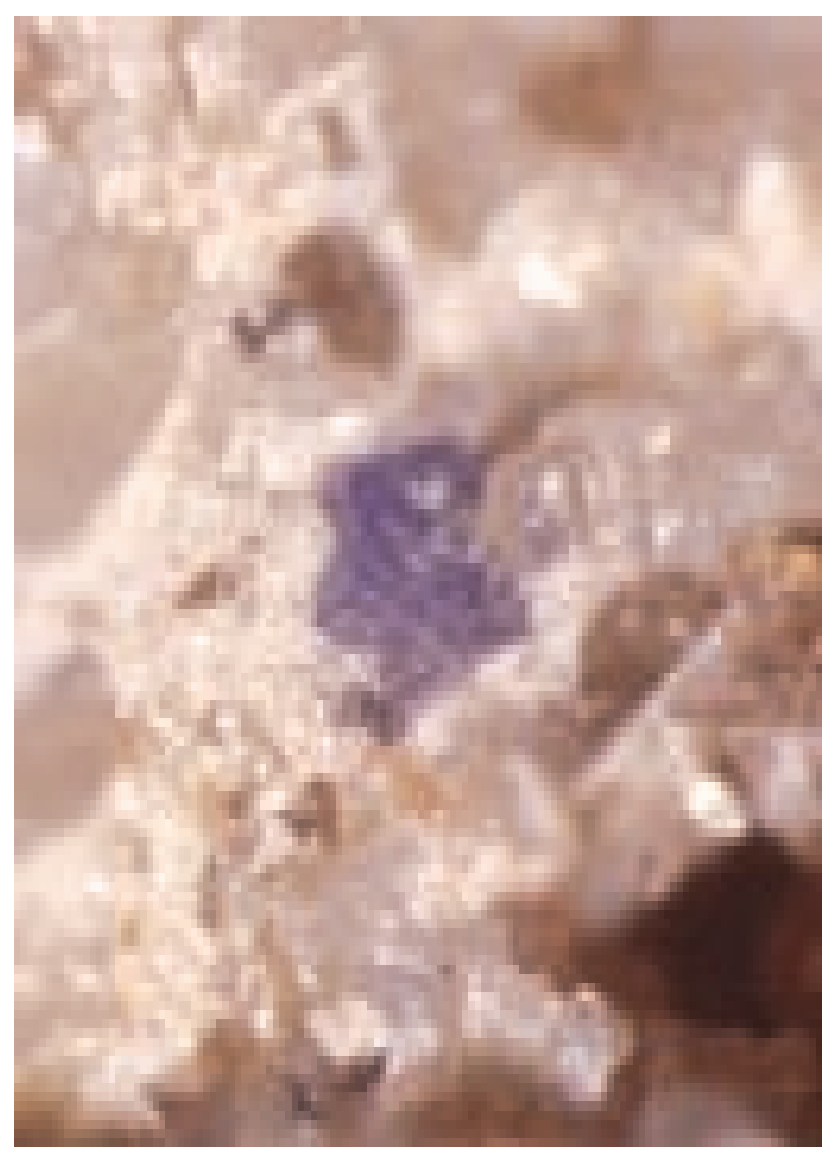

Fig. 8 Dark blue kolbeckite crystal, Krásno (feldspar) near Horní Slavkov, width of figure $2 \mathrm{~mm}$; photo J. Sejkora, Nikon SMZ1500. 
shortly prismatic morphology (Fig. 9). It occurs in quartz cavities in association with hematite, apatite and in the proximity of corroded beryl crystals. In a single case kolbeckite was found as an overgrowth on scheelite in a quartz cavity. Scandium for crystallization of kolbeckite was probably mobilized from wolframite which may contain up to $0.1 \mathrm{wt}$. \% Sc.

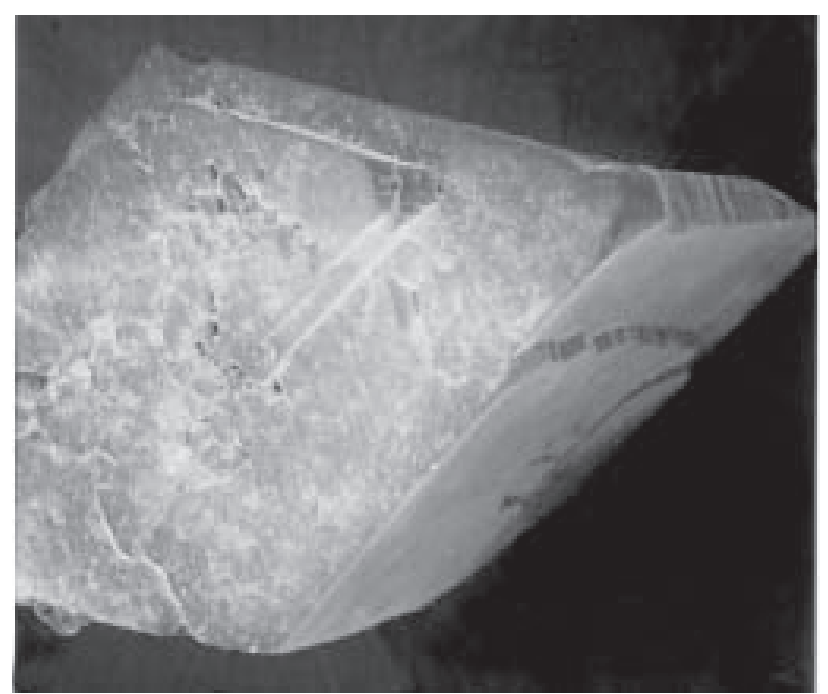

Fig. 9 Short prismatic crystal of kolbeckite. Vysoký Kámen - feldspar, Krásno, width of figure $0.6 \mathrm{~mm}$; SE photo, Tesla 320 (A. Gabašová).

X-ray diffraction pattern of a single crystal of kolbeckite (Table 6) corresponds to the published data for this mineral from Fairfield, USA (Mrose - Wappner 1959). Some differences in the intensities of diffraction maxima were probably caused by small quantity of material available for study. Identification is confirmed by microprobe analysis showing the presence of Sc and $\mathrm{P}$ as the major elements.

Table 6 X-ray powder diffraction pattern of kolbeckite

\begin{tabular}{|cccc|}
\hline \multicolumn{2}{|c|}{$\begin{array}{c}\text { Vysoký Kámen } \\
\text { Horní Slavkov }\end{array}$} & \multicolumn{2}{c|}{ Fairfield, Utah, } \\
USA* \\
\hline$I_{o b s}$ & $d_{o b s}$ & $I_{\text {tab }}$ & $d_{\text {tab }}$ \\
\hline 30 & 6.94 & 10 & 6.94 \\
30 & 5.20 & 10 & 5.25 \\
80 & 4.88 & 100 & 4.88 \\
10 & 4.56 & 95 & 4.51 \\
60 & 3.80 & 75 & 3.79 \\
10 & 3.51 & & \\
100 & 2.93 & 85 & 2.90 \\
& & 65 & 2.76 \\
30 & 2.66 & 10 & 2.66 \\
10 & 2.44 & 10 & 2.44 \\
10 & 2.33 & 10 & 2.33 \\
& & 10 & 2.24 \\
40 & 2.08 & 55 & 2.07 \\
10 & 1.877 & 10 & 1.87 \\
10 & 1.822 & 10 & 1.83 \\
\hline
\end{tabular}

Gandolfi camera $114.6 \mathrm{~mm}$, CoK $\alpha$ radiation.

* kolbeckite from Fairfield, Utah, USA (Mrose - Wappner 1959).

\section{Meta-autunite $\mathrm{Ca}\left(\mathrm{UO}_{2}\right)_{2}\left(\mathrm{PO}_{4}\right)_{2} \cdot 6 \mathrm{H}_{2} \mathrm{O}$}

See autunite.

\section{Powellite $\mathrm{CaMoO}_{4}$}

Two generations of powellite occur at the studied locality. The older generation forms grey brown to dark brown flaky aggregates up to several $\mathrm{cm}$ long which are the pseudomorphs after molybdenite. This generation of powellite fills small cavities in quartz after leached molybdenite. Large flakes of the first generation of powellite are cemented by finely crystalline light brown powellite of a younger generation. The younger generation of powellite forms druses of imperfect bipyramidal crystals (Fig. 10) of brown to grey brown colour with glassy to greasy luster (Fig. 11). The crystals which deposited on quartz are exceptionally up to $3 \mathrm{~mm}$ in size. Druses of imperfect tabular crystals of powellite $1-2 \mathrm{~mm}$ in size are rare. The first generation of powellite was partly altered to a mixture of koechlinite-russellite, so that these minerals are regularly observed in a joint occurrence. Unlike koechlinite-russellite, powellite shows light yellow fluorescence in short-wave UV light; however, powellite of the second generation exhibits a weak fluorescence.

Unit-cell parameters were calculated for the younger generation of powellite (Table 7) and show a good correspondence with the published data. The quantitative chemical analyses (Table 8) show minor abundances of $\mathrm{Mg}, \mathrm{W}, \mathrm{P}$ and As. The empirical formula based on four oxygen atoms is $\mathrm{Ca}_{1.02}\left(\mathrm{MoO}_{4}\right)_{0.96}\left(\mathrm{PO}_{4}\right)_{0.04}$. The infrared spectrum of powellite is given in Table 9 and Fig. 12.

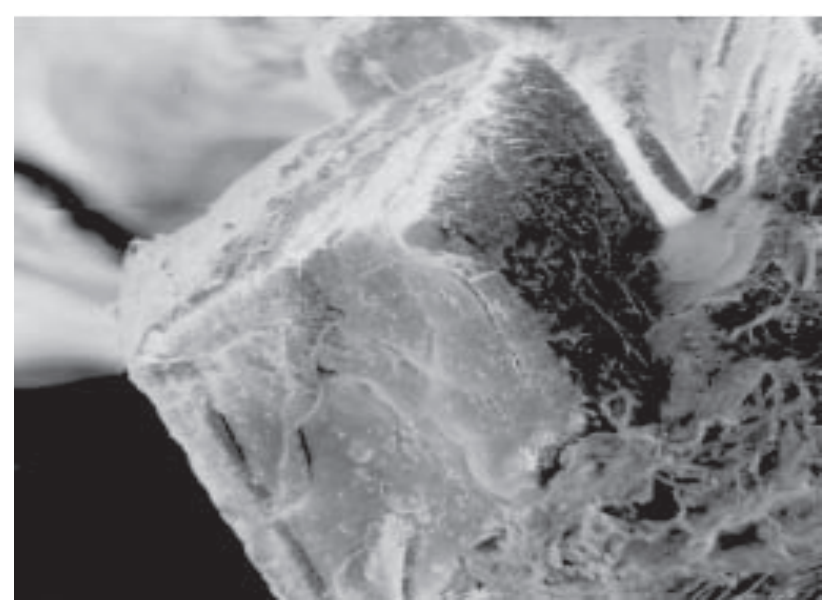

Fig. 10 Imperfect bipyramidal crystal of a younger generation powellite; Vysoký Kámen - feldpar, Krásno, width of figure $300 \mu \mathrm{m}$; SE photo, Tesla 320 (A. Gabašová).

Table 7 Unit cell parameters of powellite (tetragonal $I 4_{1} / a$ )

\begin{tabular}{|l|cc|}
\hline & this paper & Hazen et al. $(1985)$ \\
\hline $\mathrm{a}[\mathrm{A}]$ & $5.226(1)$ & $5.222(1)$ \\
$\mathrm{c}[\mathrm{A}]$ & $11.431(2)$ & $11.425(3)$ \\
$\mathrm{V}\left[\AA^{3}\right]$ & 312.2 & 311.6 \\
\hline
\end{tabular}




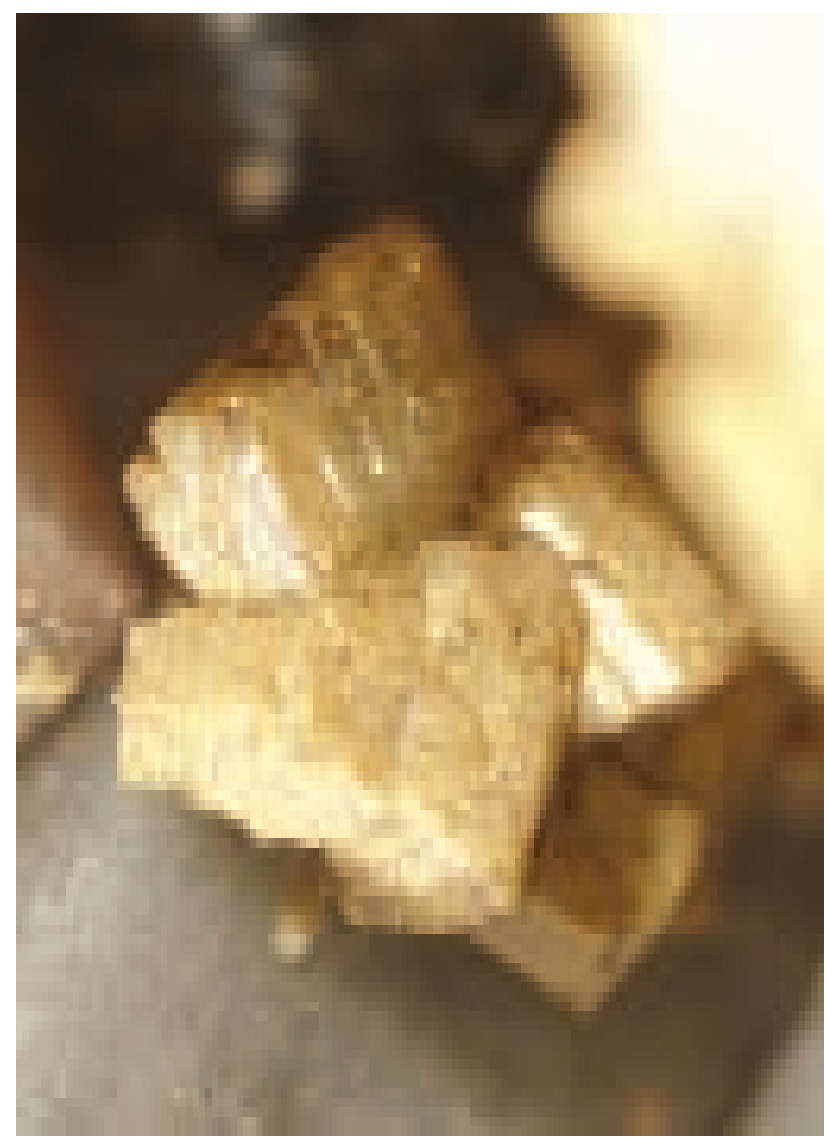

Fig. 11 Powellite crystals, Krásno (feldspar) near Horní Slavkov, width of figure $3 \mathrm{~mm}$; photo J. Sejkora, Nikon SMZ1500.

Table 8 Chemical composition of powellite from Vysoký Kámen (in wt. \%)

\begin{tabular}{|l|rc|}
\hline & Vysoký Kámen & theoretical composition \\
\hline $\mathrm{CaO}$ & 28.65 & 28.04 \\
$\mathrm{MgO}$ & 0.01 & \\
$\mathrm{P}_{2} \mathrm{O}_{5}$ & 1.41 & \\
$\mathrm{As}_{2} \mathrm{O}_{5}$ & 0.27 & \\
$\mathrm{MoO}_{3}$ & 68.74 & 71.96 \\
$\mathrm{WO}_{3}$ & 0.10 & \\
total & 99.18 & 100.00 \\
\hline
\end{tabular}

Table 9 Infrared absorption spectrum of powellite from Vysoký Kámen

\begin{tabular}{|cc|cc|}
\hline$\left[\mathrm{cm}^{-1}\right]$ & $*$ & {$\left[\mathrm{~cm}^{-1}\right]$} & $*$ \\
\hline 3400 & $\mathrm{vw}, \mathrm{b}$ & 805 & $\mathrm{vs}, \mathrm{b}$ \\
1640 & $\mathrm{vw}, \mathrm{b}$ & 695 & $\mathrm{w}, \mathrm{sh}$ \\
1095 & $\mathrm{~m}, \mathrm{sh}$ & 535 & $\mathrm{~m}$ \\
1030 & $\mathrm{~s}$ & 470 & $\mathrm{~m}$ \\
1010 & $\mathrm{~s}$ & 430 & $\mathrm{~m}$ \\
905 & $\mathrm{~m}, \mathrm{sh}$ & 320 & $\mathrm{~s}$ \\
860 & $\mathrm{~s}, \mathrm{sh}$ & & \\
\hline
\end{tabular}

* Character of absorption maxima:

sh - shoulder; b - broad. Intensity scale:

vs - very strong; $\mathrm{s}$ - strong; $\mathrm{m}$ - medium;

mw - medium weak; w - weak; vw - very weak.

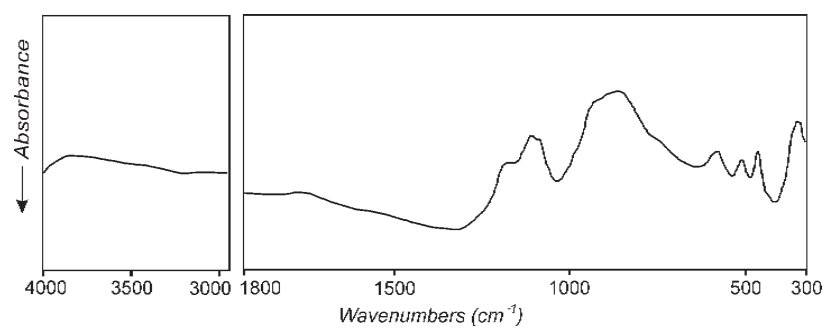

Fig. 12 The infrared spectra of powellite from Vysoký Kámen - feldpar, Krásno.

The measured absorption bands at 320,430 and $470 \mathrm{~cm}^{-1}$ correspond to $v_{2}$ and $v_{4}$ deformation vibrations of $\left(\mathrm{MoO}_{4}\right)^{2-}$, a wide high-intensity band at $805 \mathrm{~cm}^{-1}$ corresponds to $v_{3}$ valence vibrations of $\left(\mathrm{MoO}_{4}\right)^{2-}$ and another band at $860 \mathrm{~cm}^{-1}$ corresponds to $v_{1}$ vibrations of the $\mathrm{MoO}_{4}^{2-}$ anion. Very weak bands at 1640 and $3400 \mathrm{~cm}^{-1}$ are caused by adsorbed water.

\section{Scheelite $\mathrm{CaWO}_{4}$}

It is a fairly common accessory in disseminated grains to $1 \mathrm{~mm}$, associated with beryl, wolframite, koechlinite, apatite and other minerals. Exceptionally, scheelite occurred as well-formed grey crystal $1 \mathrm{~cm}$ in size, deposited in a quartz cavity and intergrown with minute kolbeckite crystals (Beran 1999).

\section{Supergene minerals identified at the Vysoký Kámen (greisen) locality}

Cacoxenite $(\mathrm{Fe}, \mathrm{Al})_{25}\left(\mathrm{PO}_{4}\right)_{17} \mathrm{O}_{6}(\mathrm{OH})_{12} \cdot 75 \mathrm{H}_{2} \mathrm{O}$

Cacoxenite belongs to relatively common minerals at the locality. It forms coatings and aggregates in fractures of a quartz breccia in the Vysoký Kámen fault zone and in the drill cores from a depth up to $40 \mathrm{~m}$ below the present level.

It occurs as radiating aggregates up to $2 \mathrm{~mm}$ in diameter, composed of very fine crystals of golden yellow colour (Fig. 13) deposited in fractures in greisen and quartz.

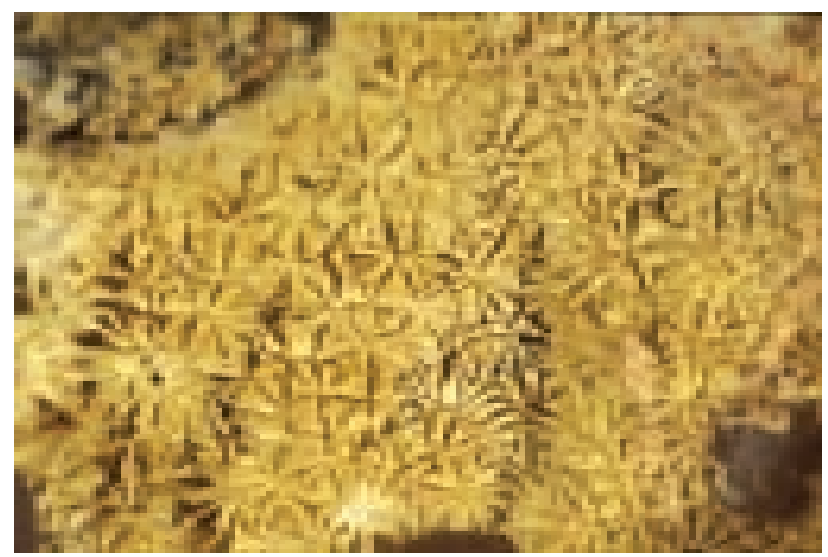

Fig. 13 Yellow crystalline crusts of cacoxenite, Krásno (greisen) near Horní Slavkov, width of figure $12 \mathrm{~mm}$; photo J. Sejkora, Nikon SMZ1500. 
The aggregates are often corroded and at margins they show alteration to oxy-hydroxides of iron (limonite). The mineral was identified by X-ray powder diffraction data.

\section{Minerals of the chalcosiderite $\mathrm{CuFe}_{6}\left[\mathrm{PO}_{4}(\mathrm{OH})_{2}\right]_{4} \cdot 4$} $\mathrm{H}_{2} \mathrm{O}$ - turquoise series $\mathrm{CuAl}_{6} \mathrm{PO}_{4}(\mathrm{OH})_{2} \mathrm{l}_{4} \cdot 4 \mathrm{H}_{2} \mathrm{O}$

Minerals of this series are common at the locality, particularly as groups of spheroidal aggregates up to $1 \mathrm{~mm}$ in diameter, in fractures of a greisen, in quartz breccia and quartz veins.

Semi-spherical aggregates occur isolated (Fig. 14), or in small groups grading to thin crusts with irregular to botryoidal surface (Fig. 15). The aggregates are bright emerald to bluish green, probably in dependence on $\mathrm{Al} / \mathrm{Fe}$ ratio. The surface of the aggregates is formed by platy crystals (Figs 16 and 17), or rare pale blue aggregates (Fig. 18) of prismatic crystals with acute terminations, which belong to the minerals close to the turquoise end-member (Figs 19 and 20).

The quantitative chemical analyses show various members ranging nearly within the whole isomorphous series (Fig. 21) and indicating chemical heterogeneity of stud-

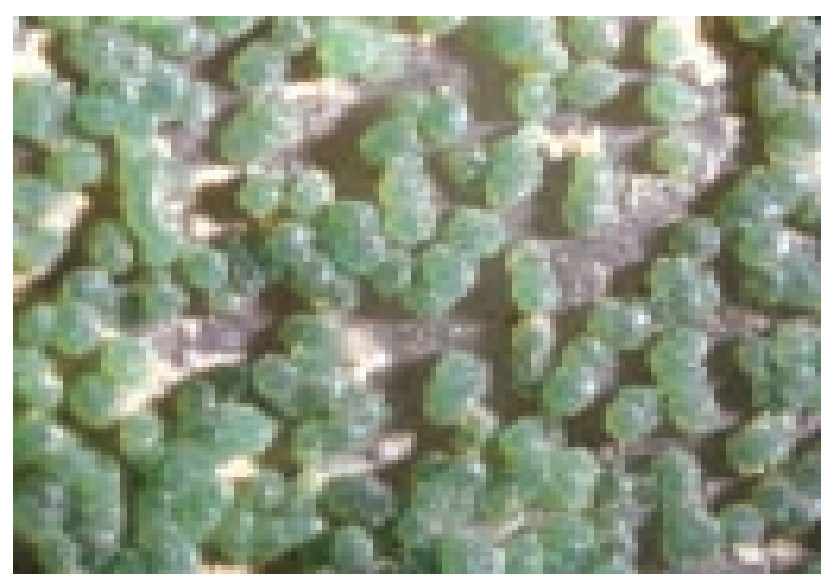

Fig. 14 Spherical chalcosiderite aggregates, Krásno (greisen) near Horní Slavkov, width of figure $20 \mathrm{~mm}$; photo J. Sejkora, Nikon SMZ1500.

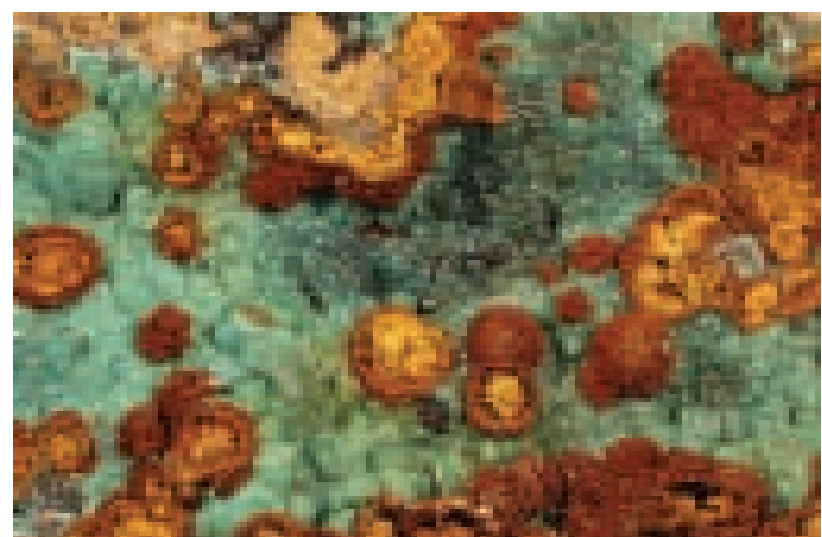

Fig. 15 Crusts formed by hemispherical aggregates of mineral of turquoise group, Krásno (greisen) near Horní Slavkov, width of figure $30 \mathrm{~mm}$; photo J. Sejkora, Nikon SMZ1500.

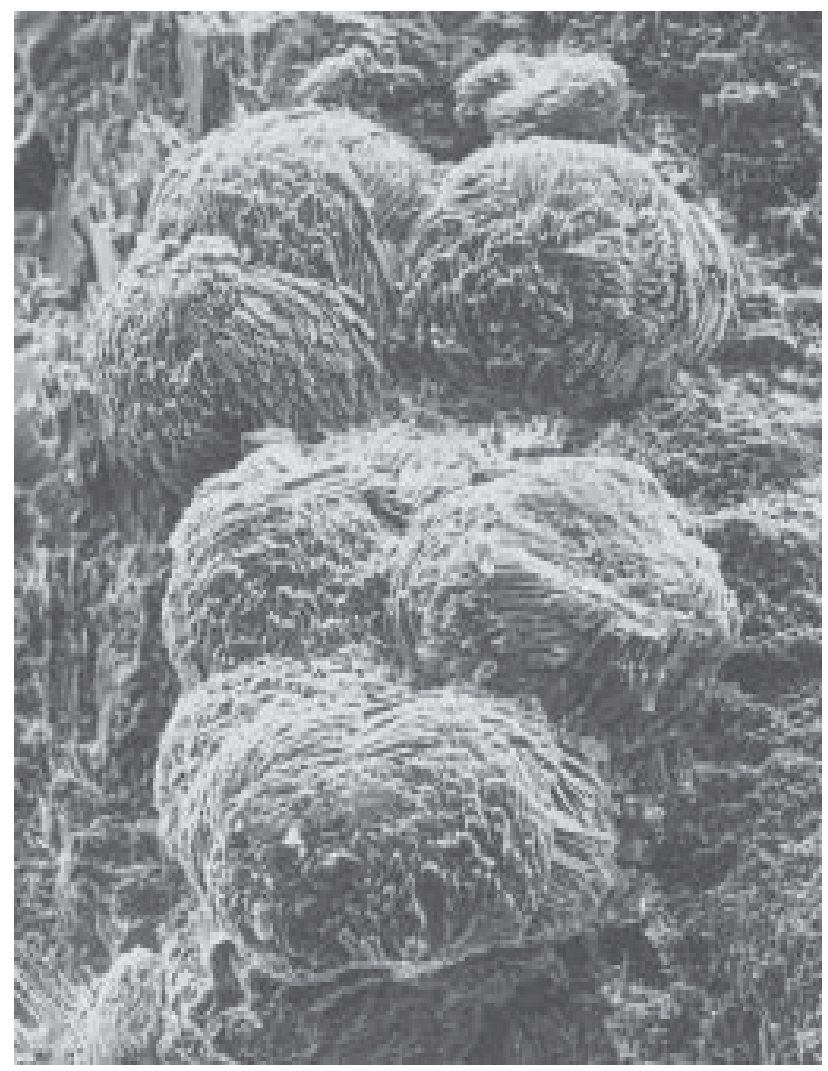

Fig. 16 Hemispherical chalcosiderite aggregates; Vysoký Kámen (greisen), Krásno, width of figure $125 \mu \mathrm{m}$; SE photo M. Fikar.

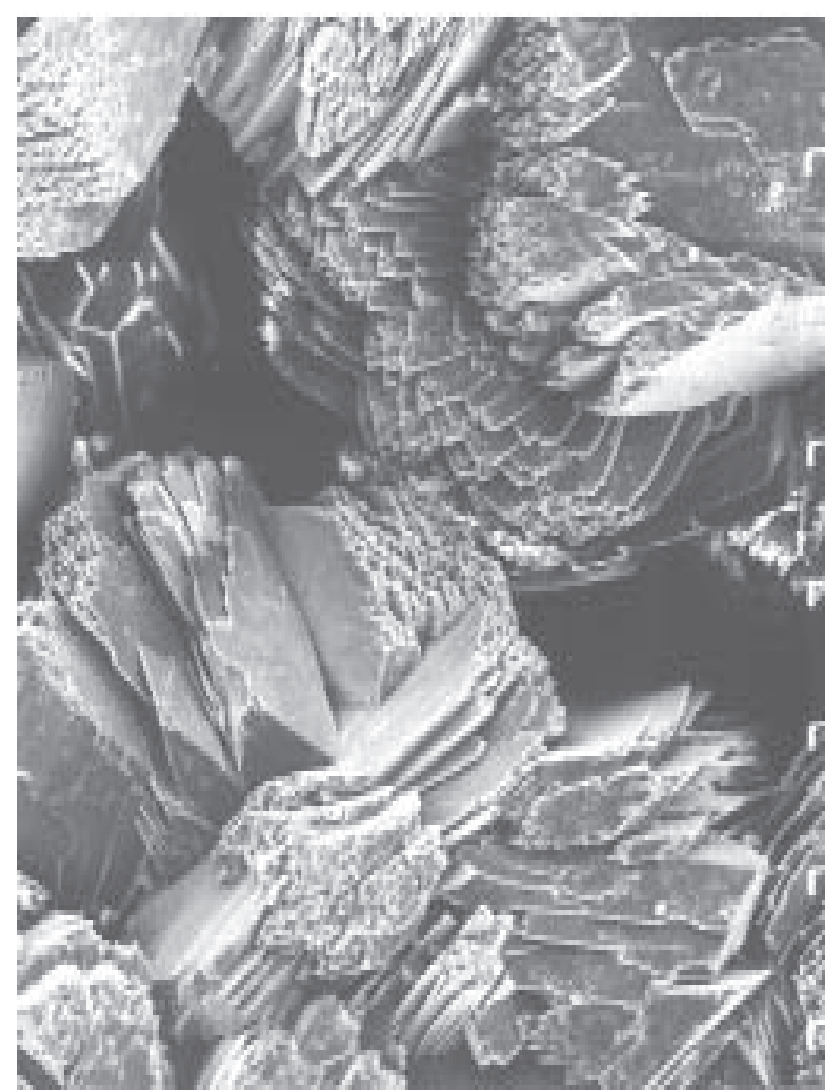

Fig. 17 Groups of chalcosiderite crystals; Vysoký Kámen (greisen), Krásno, width of figure $125 \mu \mathrm{m}$; SE photo Z. Mach. 


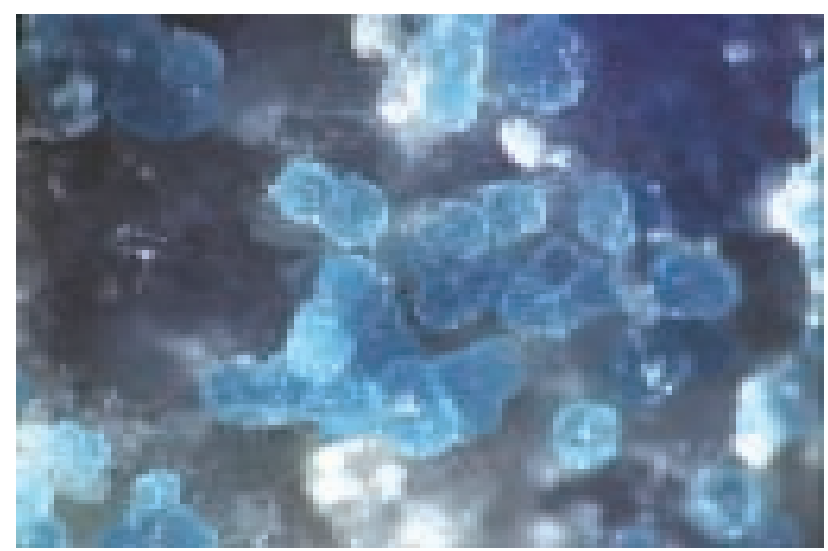

Fig. 18 Spherical turquoise aggregates, Krásno (greisen), width of figure $8 \mathrm{~mm}$; photo J. Sejkora, Nikon SMZ1500.

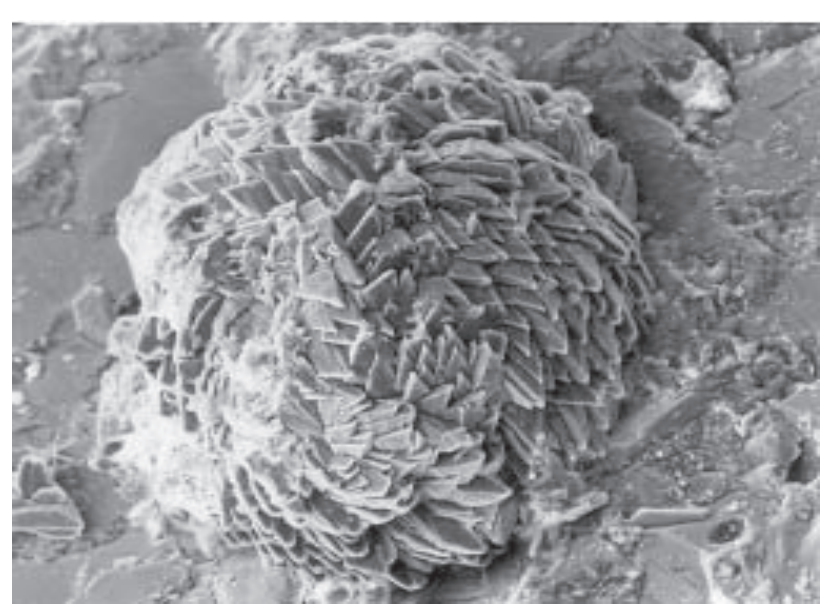

Fig. 19 Spheroidal aggregate of turquoise prismatic crystals with acute termination; Vysoký Kámen (greisen), Krásno, width of figure $450 \mu \mathrm{m}$; SE photo M. Fikar.

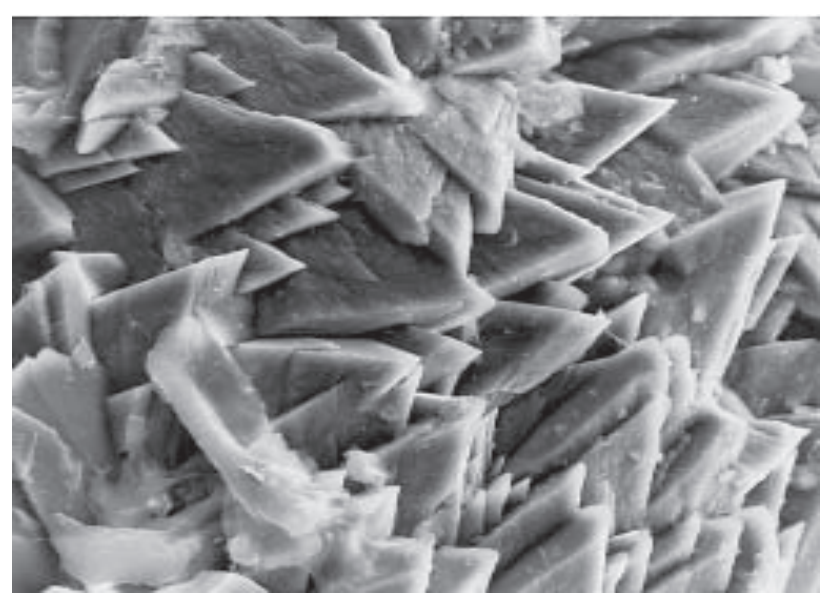

Fig. 20 Detail of turquoise crystals with acute termination; Vysoký Kámen (greisen), Krásno, width of figure $100 \mu \mathrm{m}$; SE photo M. Fikar.

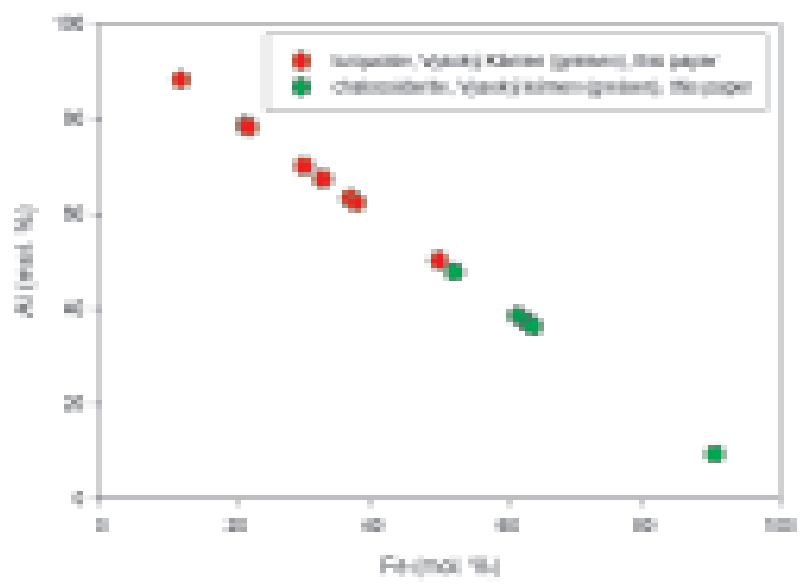

Fig. $21 \mathrm{Fe}-\mathrm{Al}$ (mol. \% of components) in minerals of the isomorphic series chalcosiderite - turquoise, Vysoký Kámen (greisen).

ied aggregates (Fig. 22). Examples of compositionally heterogeneous chalcosiderite deposited on the crusts of crystallized turquoise were found (Fig. 23). Chemical composition of selected members of the series with empirical formulas is shown in Table 10. The powder $\mathrm{X}$-ray data agree with the PDF2 database.

Table 10 Chemical composition of members of the chalcosiderite - turquoise isomorphous series from the Vysoký Kámen (greisen) deposit (in wt. \%)

\begin{tabular}{|l|rrrrrr|}
\hline & 1. & \multicolumn{1}{c}{2.} & \multicolumn{1}{c}{3.} & \multicolumn{1}{c}{4.} & \multicolumn{1}{c}{5.} & 6. \\
\hline $\mathrm{CuO}$ & 8.06 & 7.57 & 11.14 & 10.91 & 11.78 & 9.78 \\
$\mathrm{CaO}$ & & & 0.03 & 0.02 & 0.09 & \\
$\mathrm{BaO}$ & & & & & 0.27 & \\
$\mathrm{SrO}$ & & & 0.04 & & 0.10 & \\
$\mathrm{ZnO}$ & & 0.25 & & & & \\
$\mathrm{Fe}_{2} \mathrm{O}_{3}$ & 48.56 & 43.30 & 31.41 & 20.22 & 6.68 & \\
$\mathrm{Al}_{2} \mathrm{O}_{3}$ & & 2.87 & 12.58 & 22.18 & 31.97 & 37.60 \\
$\mathrm{P}_{2} \mathrm{O}_{5}$ & 28.77 & 23.85 & 31.08 & 32.43 & 33.85 & 34.90 \\
$\mathrm{As}_{2} \mathrm{O}_{5}$ & & 7.33 & 0.09 & 0.14 & 0.04 & \\
$\mathrm{SO}_{3}$ & & & & & 0.14 & \\
$\mathrm{H}_{2} \mathrm{O}^{*}$ & 14.61 & 14.38 & 15.53 & 16.68 & 17.38 & 17.72 \\
total & 100.00 & 99.55 & 101.56 & 102.57 & 102.29 & 100.00 \\
\hline
\end{tabular}

* $\mathrm{H}_{2} \mathrm{O}$ is calculated from stoichiometry, assuming the ideal formula $\mathrm{CuM}_{6}\left[\mathrm{PO}_{4}(\mathrm{OH})_{2}\right]_{4} \cdot 4 \mathrm{H}_{2} \mathrm{O}(\mathrm{M}=\mathrm{Fe}, \mathrm{Al})$ and charge balance. Empirical formulae were calculated on the basis of $28(\mathrm{O}, \mathrm{OH})$.

1. theoretical composition of chalcosiderite $\mathrm{CuFe}_{6}\left[\mathrm{PO}_{4}(\mathrm{OH})_{2}\right]_{4} \cdot 4 \mathrm{H}_{2} \mathrm{O}$ 2. composition showing the highest iron content, corresponding to empirical formula:

$\left(\mathrm{Cu}_{0.95} \mathrm{Zn}_{0.03}\right)_{\Sigma 0.98}\left(\mathrm{Fe}_{5.44} \mathrm{Al}_{0.56}\right)_{\Sigma 6.00}\left(\mathrm{PO}_{4}\right)_{3.37}\left(\mathrm{AsO}_{4}\right)_{0.64}(\mathrm{OH})_{7.96} \cdot 4.00 \mathrm{H}_{2} \mathrm{O}$.

3. chalcosiderite showing an intermediate composition corresponding to the following empirical formula:

$\mathrm{Cu}_{1.28}\left(\mathrm{Fe}_{3.55} \mathrm{Al}_{2.55}\right)_{\Sigma 5.80}\left(\mathrm{PO}_{4}\right)_{4.00}\left(\mathrm{OH}_{4}\right)_{4.00}(\mathrm{OH})_{7.98} \cdot 4.00 \mathrm{H}_{2} \mathrm{O}$.

4. turquoise showing an intermediate composition corresponding to the empirical formula:

$\mathrm{Cu}_{1.18}\left(\mathrm{Al}_{3.73} \mathrm{Fe}_{2.17}\right)_{\Sigma 5.90}\left(\mathrm{PO}_{4}\right)_{3.92}\left(\mathrm{AsO}_{4}\right)_{0.01}(\mathrm{OH})_{8.28} \cdot 4.00 \mathrm{H}_{2} \mathrm{O}$

5. specimen showing the highest recorded Al-content, corresponding to empirical formula:

$\left(\mathrm{Cu}_{1.22} \mathrm{Ca}_{0.01} \mathrm{Ba}_{0.01} \mathrm{Sr}_{0.01}\right)_{\Sigma 1.25}\left(\mathrm{Al}_{5.16} \mathrm{Fe}_{0.69}\right)_{\Sigma 5.85}\left(\mathrm{PO}_{4}\right)_{3.92}\left(\mathrm{SO}_{4}\right)_{0.04}(\mathrm{OH})_{8.24} \cdot 4.00 \mathrm{H}_{2} \mathrm{O}$ 6. theoretical composition of turquoise $\mathrm{CuAl}_{6}\left[\mathrm{PO}_{4}(\mathrm{OH})_{2}\right]_{4} \cdot 4 \mathrm{H}_{2} \mathrm{O}$ 


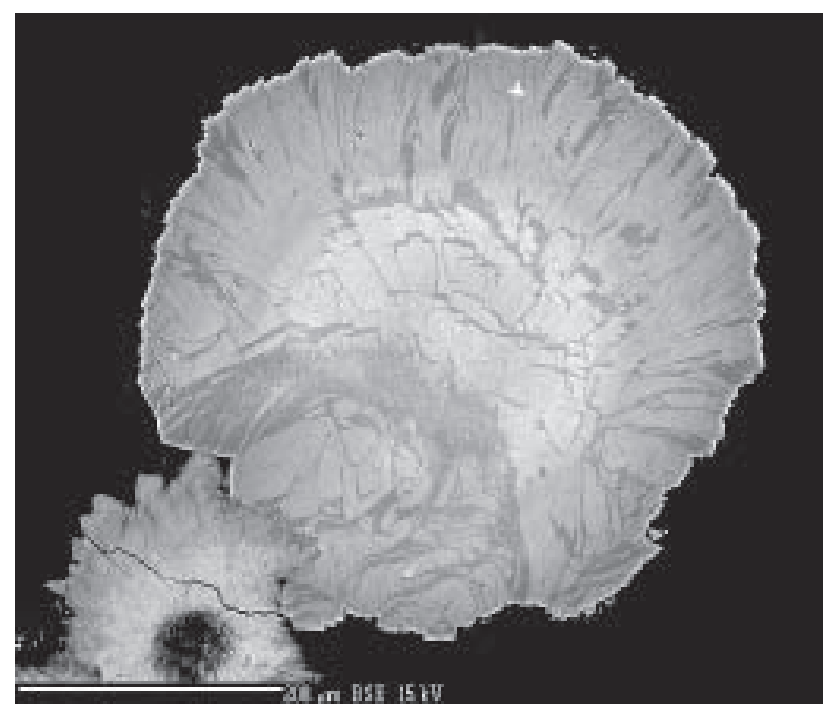

Fig. 22 Compositionally inhomogeneous aggregate of minority chalcosiderite (light coloured parts, containing about $48 \mathrm{~mol} \%$ of turquoise component) and strongly predominating, compositionally inhomogeneous turquoise, containing 21 to nearly $50 \mathrm{~mol} . \%$ of chalcosiderite component. Vysoký Kámen (greisen). BSE image, electron microprobe CAMECA SX100 (Masaryk University Brno; photo R. Škoda and J. Sejkora).

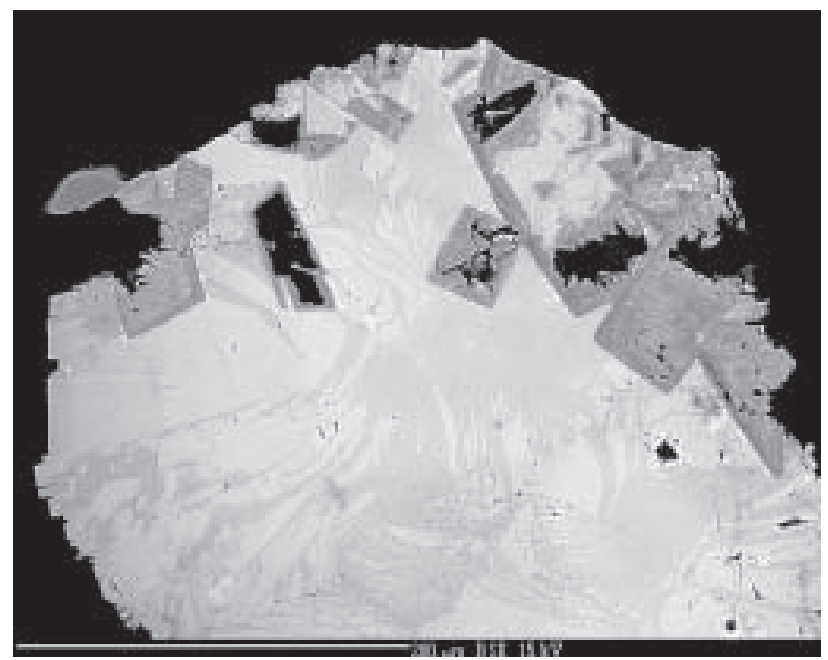

Fig. 23 Compositionally inhomogeneous semispherical aggregate of chalcosiderite containing c. 36-39 mol.\% turquoise. Well-formed crystals of turquoise at the margin (dark grey) contain only $12-22$ mol.\% chalcosiderite. Vysoký Kámen. BSE image, electron microprobe CAMECA SX100 (Masaryk University Brno; photo R. Škoda and J. Sejkora).

\section{Dickite $\mathrm{Al}_{2} \mathrm{Si}_{2} \mathrm{O}_{5}(\mathrm{OH})_{4}$}

Dickite is a frequent mineral at the deposit. The oldest generation of dickite formed during the late stages of hydrothermal mineralization. However, some dickite samples could have been of supergene origin. It forms beige white soft aggregates, deposited on a crust of light blue turquoise. Dickite coatings several $\mathrm{cm}^{2}$ in size cover quartz crystals in the cavities or turquoise-chalcosiderite crusts. The mineral was identified by X-ray powder diffraction data.

\section{Goethite $\mathrm{FeO}(\mathrm{OH})$}

Goethite occurs mostly in fractures, dominantly in association with phosphates of the turquoise-chalcosiderite series, as spherical radiating aggregates of small red brown crystals. It belongs to the youngest minerals at the deposit. The mineral was identified by X-ray powder diffraction data.

\section{Leucophosphite $\mathrm{K}(\mathrm{Fe}, \mathrm{Al})_{2}\left(\mathrm{PO}_{4}\right)_{2} \mathrm{OH} \cdot 2 \mathrm{H}_{2} \mathrm{O}$}

It occurs in a hydrothermally silicified tectonic zone in the upper part of the greisen quarry. Leucophosphite forms yellow green to grey yellow crystalline coatings and crusts on quartz. Less common are the aggregates of small, transparent and highly lustrous prismatic crystals grown on small quartz crystals (Fig. 24). Also found were spheroidal greenish aggregates up to $3 \mathrm{~mm}$ in diameter, showing radiating internal structure with drusy crystals on their surface (Fig. 25). Leucophosphite is document-

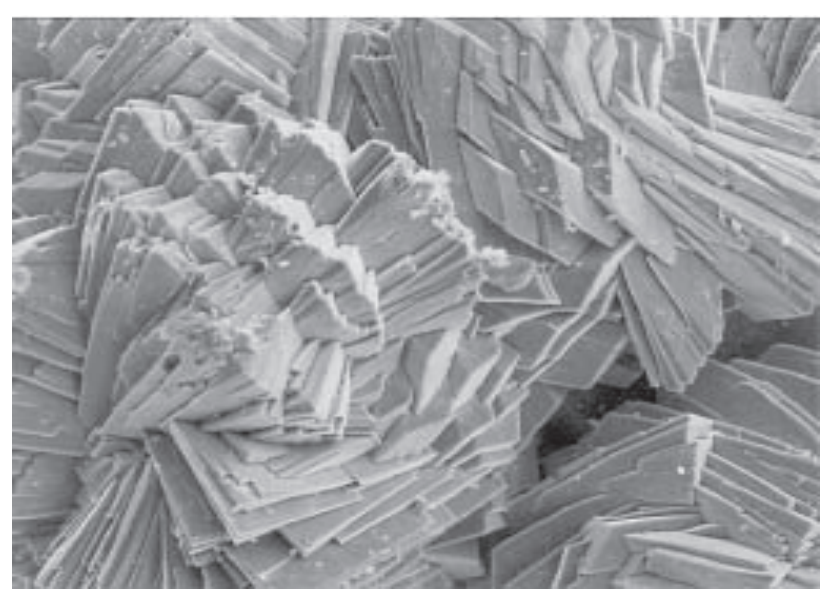

Fig. 24 Clusters of small leucophosphite crystals; Vysoký Kámen (greisen), Krásno, width of figure $500 \mu \mathrm{m}$; SE photo M. Fikar.

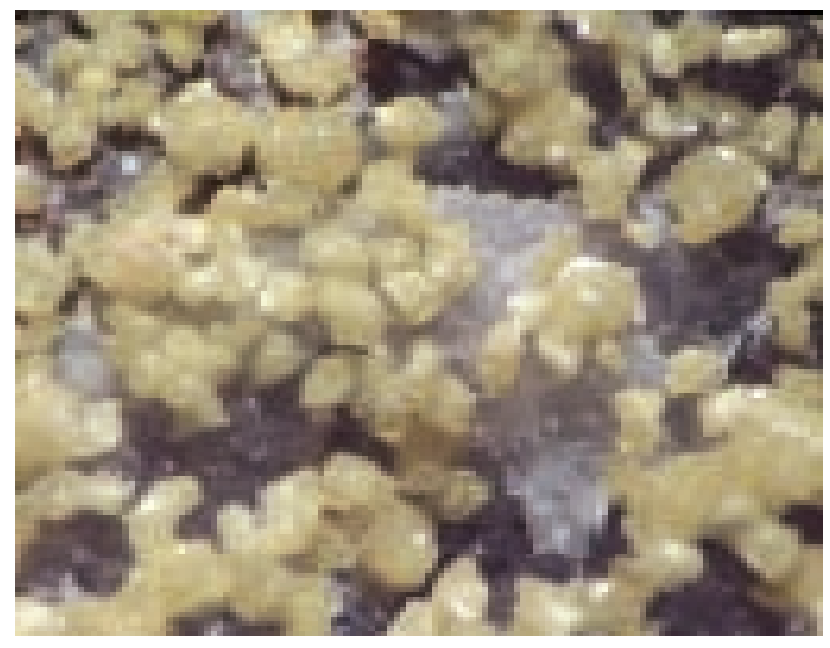

Fig. 25 Clusters of leucophosphite crystals, Krásno (greisen) near Horní Slavkov, width of figure $7 \mathrm{~mm}$; photo J. Sejkora, Nikon SMZ1500. 
Table 11 Infrared absorption spectra of leucophosphite from Vysoký Kámen

\begin{tabular}{|cc|cc|}
\hline$\left[\mathrm{cm}^{-1}\right]$ & $*$ & {$\left[\mathrm{~cm}^{-1}\right]$} & $*$ \\
\hline 3430 & $\mathrm{~s}$ & 795 & $\mathrm{~W}$ \\
3310 & $\mathrm{~s}$ & 775 & $\mathrm{vw}$ \\
2950 & $\mathrm{vw}$ & 630 & $\mathrm{vs}$ \\
2920 & $\mathrm{~W}$ & 610 & $\mathrm{~s}$ \\
2850 & $\mathrm{vw}$ & 590 & $\mathrm{~s}$ \\
1640 & $\mathrm{~m}$ & 550 & $\mathrm{~m}$ \\
1460 & $\mathrm{w}$ & 460 & $\mathrm{~s}$ \\
1380 & $\mathrm{w}$ & 425 & $\mathrm{~s}$ \\
1150 & $\mathrm{~s}, \mathrm{sh}$ & 360 & $\mathrm{~m}$ \\
1070 & $\mathrm{vs}$ & 300 & $\mathrm{w}$ \\
990 & $\mathrm{vs}$ & 232 & $\mathrm{~m}$ \\
840 & $\mathrm{~m}$ & 208 & $\mathrm{~m}$ \\
\hline
\end{tabular}

* Character of absorption maxima:

$\mathrm{sh}$ - shoulder; b - broad. Intensity scale:

vs - very strong; s - strong; $\mathrm{m}$ - medium;

mw - medium weak; w - weak; vw - very weak.

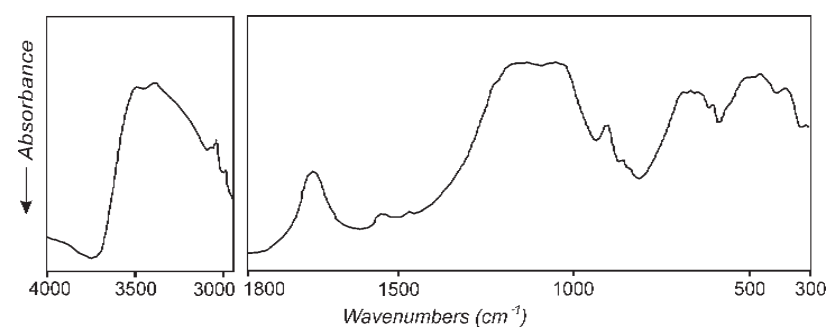

Fig. 26 The infrared spectra of leucophosphite from Vysoký Kámen (greisen), Krásno.

ed from the association with the minerals of the turquoise-chalcosiderite and variscite-strengite series. The mineral was identified by X-ray powder diffraction data. The infrared absorption spectrum of leucophosphite is shown in Table 11 and Fig. 26.

\section{Minerals of the strengite $\mathrm{FePO}_{4} .2 \mathrm{H}_{2} \mathrm{O}$ - variscite $\mathrm{AlPO}_{4} .2 \mathrm{H}_{2} \mathrm{O}$ series}

Members of the variscite-strengite series occur along fractures and in the cavities of greisen as minute grey

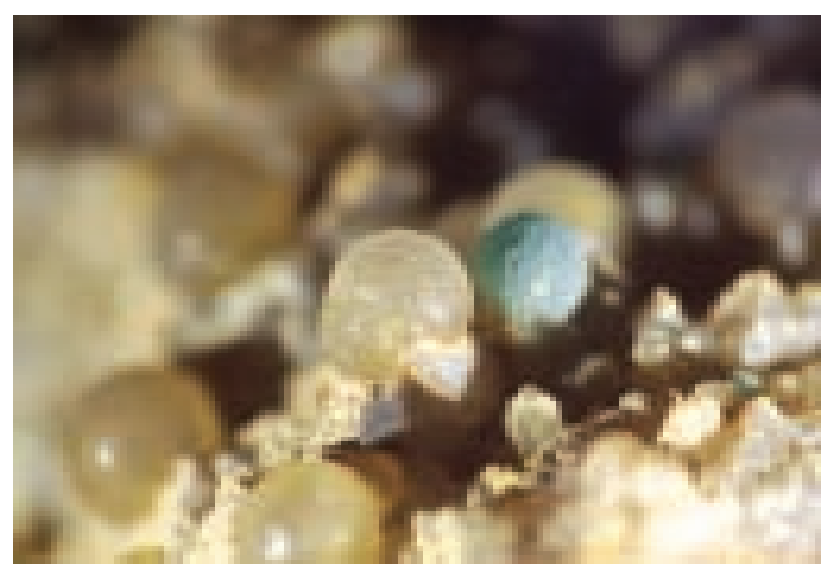

Fig. 27 Yellowish spherical aggregates od strengite, Krásno (greisen), width of figure $10 \mathrm{~mm}$; photo J. Sejkora, Nikon SMZ1500. white coatings with a botryoidal surface and a radiatingfibrous internal structure. Grey and light violet spheroidal aggregates 1 to $2 \mathrm{~mm}$ in diameter (Fig. 27) and with a drusy surface, composed of pyramidal crystals $0.1 \mathrm{~mm}$

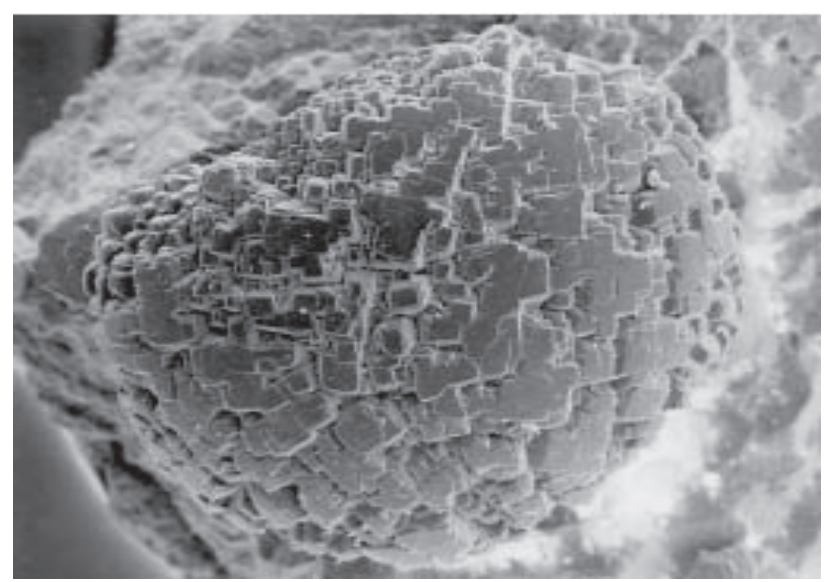

Fig. 28 Light violet, radiating spheroidal aggregate of strengite; Vysoký Kámen (greisen), Krásno, width of figure $2 \mathrm{~mm}$; SE photo M. Fikar.

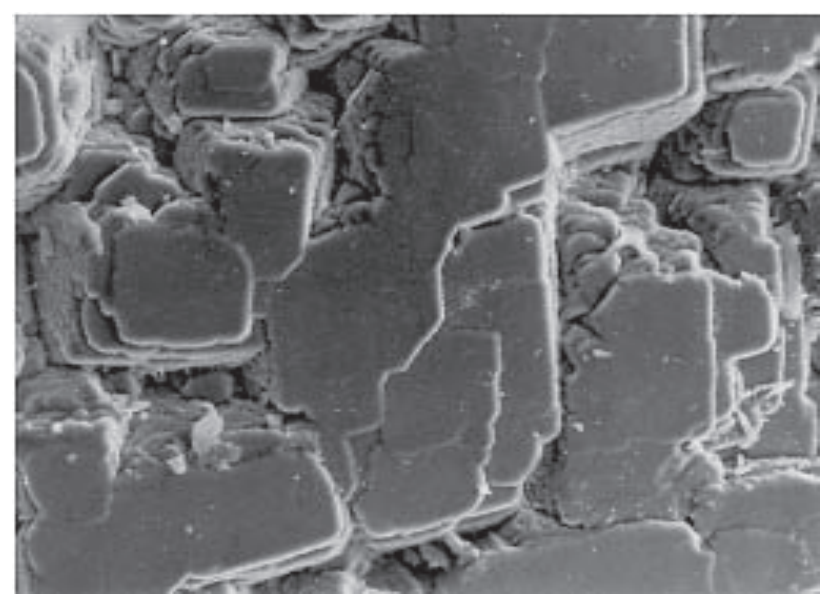

Fig. 29 Detail of the surface of spheroidal strengite aggregate composed of pyramidal crystals; Vysoký Kámen (greisen), Krásno, width of figure $300 \mu \mathrm{m}$; SE photo M. Fikar.

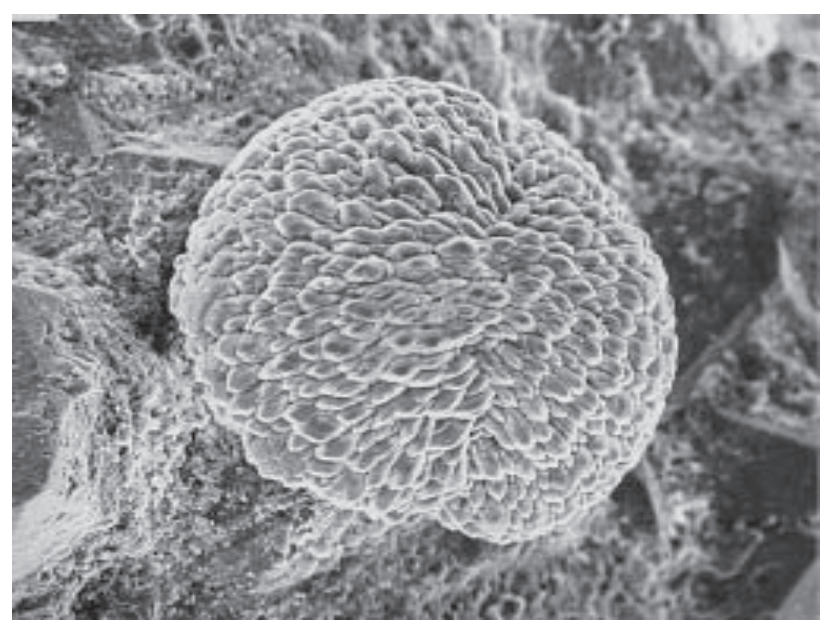

Fig. 30 Spheroidal aggregates of pyramidal variscite crystals deposited on quartz crystals; Vysoký Kámen (greisen), Krásno, width of figure $5 \mathrm{~mm}$; SE photo A. Gabašová. 


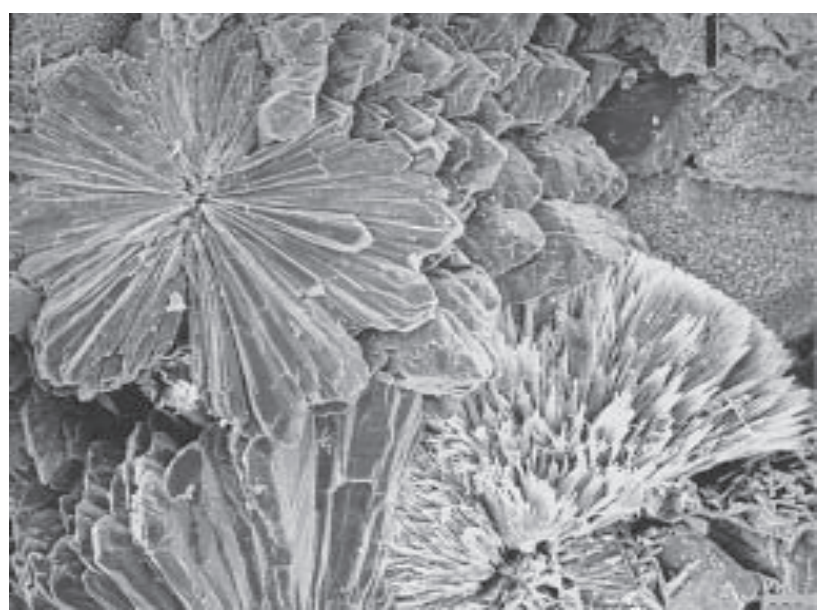

Fig. 31 Detail view of an aggregate of pyramidal variscite crystals; Vysoký Kámen (greisen), Krásno, width of figure $1.1 \mathrm{~mm}$; SE photo Z. Mach.

long (Figs 28 and 29), occur in association with leucophosphite and chalcosiderite. The morphology of the variscite crystals is shown in Figs 30 and 31. The minerals of this isomorphous series have been identified in addition to X-ray powder diffraction also by semiquantitative chemical analyses. All the samples analyzed contain $\mathrm{Al}$ and Fe. Pure end members of the series are unknown at this locality.

\section{Turquoise $\mathrm{CuAl}_{6}\left[\mathrm{PO}_{4}(\mathrm{OH})_{2}\right]_{4} \cdot 4 \mathrm{H}_{2} \mathrm{O}$}

See minerals of the series chalcosiderite-turquoise.

\section{Variscite $\mathrm{AlPO}_{4} .2 \mathrm{H}_{2} \mathrm{O}$}

See minerals of the strengite-variscite series.

\section{Vivianite $\mathrm{Fe}_{3}\left(\mathrm{PO}_{4}\right)_{2} .8 \mathrm{H}_{2} \mathrm{O}$}

Vivianite was observed rarely in cavities, deposited on white quartz grading to amethyst in the fractures of jasper and in the greisen in the southern part of the quarry. It forms typical radiating aggregates composed of dark blue green to black green crystals (Fig. 32) with acute termination, which are up to $3 \mathrm{~mm}$ long. Vivianite occurs in association with cacoxenite, minerals of the turquoise-chalcosiderite series and strengite-variscite. Vivianite was identified by X-ray powder diffraction.

\section{Wavellite $\mathrm{Al}_{3}\left(\mathrm{PO}_{4}\right)_{2}(\mathrm{OH}, \mathrm{F})_{3} .5 \mathrm{H}_{2} \mathrm{O}$}

Wavellite occurs in association with other phosphates as grey white coatings with a fibrous internal structure. Exceptionally it forms radiating aggregates with older turquoise or chalcosiderite in their centres. Wavellite belongs to the youngest phosphates at the deposit. It was identified by X-ray powder diffraction.

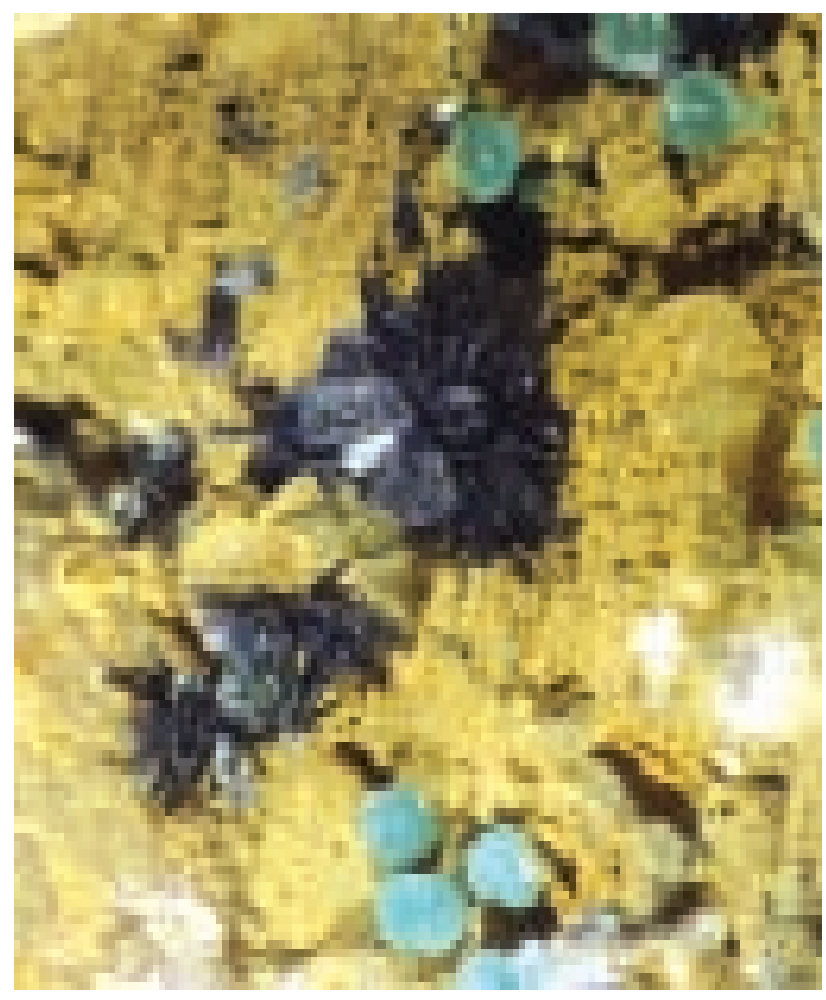

Fig. 32 Dark blue groups of vivianite tabular crystals, Krásno (greisen), width of figure $10 \mathrm{~mm}$; photo J. Sejkora, Nikon SMZ1500.

\section{Interpretation of supergene mineral assemblages at the Vysoký Kámen deposit}

\section{Vysoký Kámen (feldspar)}

Weathering processes, which took place at this locality and resulted in formation of supergene minerals, represent several distinct sets of conditions. In a general way, they include a range of processes from probably late hydrothermal to supergene (recent). Leaching and decomposition of beryl, molybdenite and wolframite belong to an early episode of alteration. The resulting supergene minerals, including bertrandite, powellite (in pseudomorphs after molybdenite) and scheelite belong to the oldest ones. They are followed by a younger generation of powellite and by kolbeckite. Koechlinite-russellite, autunite and meta-autunite belong to the latest stages of supergene alteration. Koechlinite-russellite replaced powellite; $\mathrm{Bi}$ necessary for crystallization of this mineral was provided by native bismuth. There are indications for several generations of koechlinite-russellite, autunite and metaautunite. Thus, an early generation of autunite crystals was observed in cavities with quartz. The youngest generation of meta-autunite occurs relatively often as an inconspicuous phase in aggregates of clay minerals. Younger koechlinite-russellite occurs in small cavities after leached molybdenite. The youngest mineral in this association is goethite, observed in some vugs and along fractures. 


\section{Vysoký Kámen (greisen)}

A relatively simple association of phosphates formed in a breccia zone, partly healed by quartz, and in neighbouring parts of fractured greisen. Leucophosphite, as the oldest mineral, and members of the variscite-strengite series are probably related to a closing stage of hydrothermal alteration. Younger phosphates of the turquoise-chalcosiderite series occur in fractures of greisens and quartz gangue. The complicated compositional zoning in minerals of the variscite-strengite and turquoise-chalcosiderite series indicates significant changes in chemical composition of solutions, including especially variation in the $\mathrm{Al} / \mathrm{Fe}^{3+}$ ratio. Cacoxenite, vivianite and goethite, as the youngest members of this mineralization, indicate absolute dominance of $\mathrm{Fe}^{3+}$ above $\mathrm{Al}^{3+}$ during the closing stages of supergene mineralization at this locality.

Acknowledgements. The present authors thank Pavel Beran (Regional Museum, Sokolov), Radek Škoda (Faculty of Science, Masaryk University, Brno), Jiří Litochleb (National Museum, Prague) and Stanislav Vrána (Czech Geological Survery, Prague) for co-operation on this project. Our thanks also go to numerous colleagues, who loaned or provided samples for study - Anna Sabová (Květná), Ctibor Süsser (Sokolov), Jaromír Tvrdý (Karlovy Vary) and others. This study was financially supported by the Ministry of Culture of the Czech Republic (Project MK00002327201) a Granting Agency of the Czech Republic (Grant No. 205/03/D004).

Submitted July 12, 2006

\section{References}

Beran, $P$. (1999): Minerals of tin-tungsten deposits from Slavkovský les area. - Regional museum and library in Sokolov. Sokolov, $287 \mathrm{pp}$. (in Czech).

Giuseppetti, G. - Tadini, C. - Mattioli, V. (1992): Bertrandite, $\mathrm{Be}_{4} \mathrm{Si}_{2} \mathrm{O}_{7}(\mathrm{OH})_{2}$, from Val Vigezzo (NO) Italy: the X-ray structural refinement. - N. Jb. Miner. Mh., 13-19.

Hazen, R. M. - Finger, L. W. - Mariathasan, J. W. E. (1985): High pressure crystal chemistry of scheelite-type tungstates and molybdates. Journ. Phys. Chem. Solids, 46: 253-263.

Makarov, E. S. - lvanov, V. I (1960) Crystal structure of metaautunite. Doklady Akad. Nauk SSSR, 132: 673-676 (in Russian).

Mrose, M. E. - Wappner, B. (1959): New data on the hydrated scandium phosphate minerals: sterrettite, "eggonite" and kolbeckite. - Bull. Geol. Soc. Amer., 70: 1648-1649.

Ondruš, P. (1993): ZDS - A computer program for analysis of X-ray powder diffraction patterns. - Materials Science Forum, 133-136: 297300, EPDIC-2. Enchede.

Ondruš, P. - Skála, R. (1997): New quasi-emirical channel Search/Match algorithm for ICDD PDF2 Database: A tool for qualitative phase analysis integrated in the ZDS-System software package for X-ray powder diffraction analysis - Fifth European Powder Diffraction Conference EPDIC-5, 193. Parma.

Pauliš, P. (1990): Autunite from Vysoký Kámen (Krásno) near Horní Slavkov, short communication. - Čas. Mineral. Geol., 90, 1. (in Czech).

Philibert, J. A. (1963): A metod for calculation of the absorption correction in electron probe microanalysis. - In: Petee, H. R. - Colser, V. E. - Engstrom, A. (eds.): X-ray optics and X-ray microanalyse. Academic Prew., New York, London.

Pouchou, J. L. - Pichoir, F. (1985): "PAP" procedure for improved quantitative microanalysis. - Microbeam Analysis, 20: 104-105.

Rodríguez-Carvajal, J. (2005): Computer Program FullProf, ver. December 2005. - Laboratoire Leon Bril-louin (CEA-CNRS), France.

Teller, R. G. - Brazdil, J. F. - Grasselli, R. K. - Jorgensen, J. D. (1984): The structure of gamma-bismuth molybdate, $\mathrm{Bi}_{2} \mathrm{MoO}_{6}$, by powder neutron diffraction. - Acta Cryst. C40: 2001-2005.

\section{Nové poznatky o mineralogii ložisek Vysoký Kámen u Krásna (Slavkovský les, Česká republika)}

Podrobný mineralogický výzkum byl zaměřen na dvě ložiska lokalizovaná na svazích kóty 819,4 m Vysoký Kámen u Krásna (u Horního Slavkova, Česká republika). V materiálu z činného lomu těžíćho živcovou surovinu (zejména feldspatity jako součást pně granitu mladšího intruzivního komplexu) byly zjištěny autunit, bertrandit, beryl, goethit, hematit, koechlinit, kolbeckit, meta-autunit, powellit a scheelit. Na opuštěném greisenovém ložisku byla vedle dickitu a goethitu zjištěna minerální asociace fosfátů zastoupená kakoxenem, leukofosfitem, vivianitem, wavellitem a minerály série chalcosiderittyrkys. V práci je podána i stručná interpretace vzniku popisovaných minerálních asociací. 